Advance Journal of Food Science and Technology 14(3): 77-92, 2018

DOI:10.19026/ajfst.14.5841

ISSN: 2042-4868; e-ISSN: 2042-4876

(C) 2018 Maxwell Scientific Publication Corp.

Submitted: November 3, 2017

Accepted: January 18, 2018

Published: April 25, 2018

\title{
Research Article Influence of the Composition of Coconut-Based Emulsions on the Stability of the Colloidal System
}

\author{
${ }^{1,2}$ Lucas Aguirre Juan Carlos, ${ }^{1}$ Tobón Castrillón Cynthia and ${ }^{1}$ Cortés Rodríguez Misael \\ ${ }^{1}$ Universidad Nacional de Colombia-Sede Medellín. Calle 59 A N 63-20, Medellín, Colombia \\ ${ }^{2}$ Universidad del Quindío-Armenia, Carrera 15 Calle 12 Norte, Colombia
}

\begin{abstract}
The object of this research was to determine the influence of the composition of coconut milk-based emulsions on its physical and chemical stability. Coconut represents a highly important product globally and its competitiveness is restricted to its commercialization in the form of cakes, flour and coconut oil mainly to the European Community. The search for new alternatives to diversification of products as raw materials for food, pharmaceutical and cosmetic sectors represents a potential challenge. Coconut Pulp (CP) was milled with its Coconut Water $(\mathrm{CW})$, separating the Coconut Fiber (CF), which was then dried at $40^{\circ} \mathrm{C}$ and milled for its use in emulsions and homogenized at $10.000 \mathrm{rpm}$ during $10 \mathrm{~min}$. The surface response methodology was used with a composite central design (21 experiments), considering the independent variables: $\left(\mathrm{CW}+\mathrm{H}_{2} \mathrm{O}\right) / \mathrm{CP}(1.5-2.5)$; xanthan gum $\left(\mathrm{G}_{\text {Xanthan }}\right): 0.25-0.75 \%$, CF: 2.5-7.5\%; tert-butyl hydroquinone (TBHQ): $100-200 \mathrm{mg} / \mathrm{kg}$. In addition, dairy serum was used as surfactant and salt. The multiple regression method was used to predict the linear and quadratic terms and the interaction of the independent variables in the models. The optimal conditions were: $\left(\mathrm{CW}+\mathrm{H}_{2} \mathrm{O}\right) / \mathrm{CP}$ : 2.0; $\mathrm{G}_{\text {Xanthan }}: 0.5 \%$, CF: $5.0 \%$; TBHQ: $200 \mathrm{mg} / \mathrm{kg}$, reaching potential $-\zeta:-45.578 \pm 2.478 \mathrm{mV}$, index of stability through spectral absorption $(\mathrm{R}): 0.851 \pm 0.025$; viscosity $(\mu)$ : $741.7 \pm 25.5 \mathrm{cP}$, color $\left(\mathrm{L}^{*}: 67.5 \pm 0.7\right.$, a* $3.2 \pm 0.2$, $\left.\mathrm{b}^{*}: 8.6 \pm 0.5\right)$, Peroxide index (PI): $0.142 \pm 0.038 \mathrm{meqH}_{2} \mathrm{O}_{2} / \mathrm{kg}$, particle size $\left(\mathrm{D}_{10}: 4.3 \pm 0.8 \mu \mathrm{m}, \mathrm{D}_{50}: 323.7 \pm 43.6 \mu \mathrm{m}\right.$ and $\left.\mathrm{D}_{90}: 743.0 \pm 65.1 \mu \mathrm{m}\right)$ and Total Solids (TS): $19.981 \pm 0.303 \%$. The results confer good physicochemical stability in the colloidal system studied, which could guarantee its effective use in the subsequent process, like in spray drying to obtain coconut powder.
\end{abstract}

Keywords: Cocos nuciferaL.,colloids, fiber, physicochemicalstability, peroxide index, potential- $\zeta$

\section{INTRODUCTION}

Coconut (Cocos nucifera Linn) is a palm tree from the Arecaceae family broadly distributed in tropical and subtropical climates, it is known as the tree of life due to the use of the totality of the $\mathrm{CP}, \mathrm{CW}$, husk, shell, wood, leaves, spikelet, etc. The fruit has an endosperm (CP), CW and a very hard husk or shell. The CP provides important food constituents, highlighting its water content (51.9\%), fatty acids principally lauric and myristic acids (26.1\%), carbohydrates (15.1\%), vitamins $\mathrm{C}$, thiamine, riboflavin, niacin; and minerals, like iron, calcium and phosphorus, which provide 293 kcal of energy (Ochoa-Velasco et al., 2014).

The endosperm is economically the most important part of the fruit, providing products, like copra, coconut oil and coconut milk (Siriphanichet al., 2011). Coconut milk is a natural emulsion of oil in water, thermodynamically unstable, obtained from the aqueous extraction of the endosperm and used as a food ingredient to provide creaminess and unique aroma in culinary, especially in regions of Asia and the Pacific. Additionally, the composition of coconut milk, including the protein, varies according to the coconut's variety, age, growth environment and the method and conditions used in the extraction process (Tangsuphoom and Coupland, 2008). Some researchers have indicated that coconut milk contains approximately $54 \%$ humidity, $35 \%$ fat and $11 \%$ without solid fat (Simuanget al., 2004; Tangsuphoom and Coupland, 2008).

Coconut is freely used as a refreshing beverage and as an ingredient in confectionery, ice cream, cookies, cakes and bread (Solangi and Iqbal, 2011; Appaiahet al., 2015). Oil extracted from coconut is used as cooking oil, hair oil, lamp oil and as an essential ingredient in soap manufacture (Solangi and Iqbal, 2011). Coconut water is an outstanding natural beverage that is gaining popularity in the field of sports science and the beverage industry, given its high

Corresponding Author: Juan Carlos Lucas Aguirre, Universidad Nacional-Sede Medellín, Universidad del Quindío, Colombia, Tel.: +3113392496

This work is licensed under a Creative Commons Attribution 4.0 International License (URL: http://creativecommons.org/license s/by/4.0/). 
nutritional value because it contains salts, sugars and vitamins, effectively replenishing electrolytes lost during exercise (Tan et al., 2014;Prado et al., 2015). In addition, it is attributed to potential therapeutic properties, including prevention and relief of many health problems: dehydration, constipation, digestive problems, fatigue, sunstroke, diarrhea, kidney stones and urinary tract infections (DebMandal and Mandal, 2011;Tan et al., 2014) and an antiaging effect (Ge et al., 2006; Prado et al., 2015). A sub-product of the coconut agroindustry is the fiber obtained after extracting the coconut milk, which has an important content as a dietary fiber with health implications, including the prevention of chronic disease, such as cancer, cardiovascular disease and diabetes mellitus (Raghavendra et al., 2006; Trinidad et al., 2006; Yalegamaet al., 2013).

Emulsions and dispersions are colloidal systems thermodynamically unstable from a physicochemical point of view; rapidly or slowly, they can show phase separation (Piorkowski and McClements, 2014). System stabilization is achieved normally by adding to the colloidal system surfactant components of amphiphilic nature (polysorbates, phospholipids, among others) and/or proteins and/or thickening agents (gums, gelatin, among others). The stability of colloidal systems, according to the Derjaguin-Landau-VerweyOverbeek (DLVO) theory, is generally governed by the combination of Van der Waals forces and electrostatic repulsion to obtain a global interaction potential between two particles, in function of their distance, when these are in an ionic medium (electrocratic colloids) (Piorkowski and McClements, 2014; Mirhosseiniet al., 2008). Further, other types of forces interact, like steric, hydration, hydrophobic and phase separation forces (Piorkowski and McClements, 2014).

The aim of the research was to evaluate the influence of the composition of coconut-based emulsions, native fiber, antioxidant and other additives on the stability of the colloidal system, for use in spray drying.

\section{MATERIALS AND METHODS}

The study used coconuts (Cocos nuciferaL.) 'EnanoMalayo' (Manila) or 'Alto Pacífico' (typical) varieties from the Colombian Pacific region, with flowering age to the harvest of approximately 12 months and postharvest time between 15 and 36 days. The emulsion formulation used additives, like TertButyl Hydroquinone (TBHQ) (Team) as antioxidant agent E-319, G Ganthan 200 mesh as a stabilizer, dairy serum instant WCP 80 as a surfactant and table salt (Refisal) to increase repulsive forces and the system's stability.

Characterization of the coconut and emulsions was carried out by using the following methodologies: humidity was determined according to the official AOAC method 930.15/90. pH was determined by using a potentiometer through immersion of the electrode in the sample, with prior calibration with buffer solutions at $\mathrm{pH} 2,4,7$ and 10 at $25^{\circ} \mathrm{C}$ (AOAC (Association of Official Analytical Chemists), 1990 method 981.12/90). Soluble solids were determined via refractometric reading (AOAC (Association of Official Analytical Chemists), 1990 method 932.12/90). Coconut water acidity was determined through the potentiometric titration method (AOAC method 942.05/90), expressed in malic acid and for $\mathrm{CP}$ the acidity index was determined in terms of the lauric acid. Water activity $\left(a_{w}\right)$ was determined with a spray point hygrometer at $25^{\circ} \mathrm{C}$ (Aqualab series 3TE, Decagon, Devices, Pullman, WA, USA) (Cortés and Chiralt, 2008). The peroxide index (PI) was determined through a spectrophotometric method based on the capacity of peroxides to oxidize ferrous ions into ferric ions that react with diverse reagents that produce colored complexes (Hornero-Méndez et al., 2001). The PI serves as a useful indicator of the degree of oxidation of lipids, fats and oils and was expressed as meq of $\mathrm{H}_{2} \mathrm{O}_{2} / \mathrm{kg}$ sample Eq. (1), where $\mathrm{A}_{\mathrm{m}}$ and $\mathrm{A}_{b}$ correspond to the absorbance of the sample and the target, respectively, at a 500-nm wavelength; $\mathrm{m}=$ slope of the calibration curve; $\mathrm{W}=$ sample weight $(\mathrm{g}) ; 2=$ conversion factor to express as meq $\mathrm{H}_{2} \mathrm{O}_{2}, 55.84=$ molecular weight of iron and $\mathrm{V}_{\mathrm{t}}=$ final volume $(\mathrm{mL})$ of the reaction mix was used to quantify the raw matter and the emulsion:

$$
\frac{\text { meqH }_{2} \mathrm{O}_{2}}{\text { kg sample }}=\frac{\left(\mathrm{A}_{\mathrm{m}}-\mathrm{A}_{\mathrm{b}}\right) * 1 / \mathrm{m}}{\mathrm{w} * 2 * 55.84} * \mathrm{~V}_{\mathrm{t}}
$$

The extractable oil content was determined according to the method described by Bae and Lee modified (2008). One gram $( \pm 0.0001)$ of the sample was weighed in a $15-\mathrm{mL}$ glass tube and $4 \mathrm{~mL}$ of water $\left(40^{\circ} \mathrm{C}\right)$ was added and agitated with a vortex for $2 \mathrm{~min}$. The initial mixture was mixed with $25 \mathrm{ml}$ of hexane/isopropanol solution $(3: 1 \mathrm{v} / \mathrm{v})$ agitating for 5 $\mathrm{min}$; then, it was centrifuged at $3000 \mathrm{rpm} / 2 \mathrm{~min}$, separating the organic phase, which was thereafter heated to $70^{\circ} \mathrm{C} / 5 \mathrm{~h}$. The extractable oil content was quantified as a difference of weights before and after heating. The Color was determined by using an X-Rite spectrophotometer with illuminant $\mathrm{D}_{65}$ and a $10^{\circ}$ observer as a reference. From the reflection spectra, color coordinates were obtained from CIE-La*b*, where $\mathrm{L}^{*}$ is an indicator of the luminosity, $\mathrm{a}^{*}$ (chromaticity green $(-)$ a red $(+)$ ) and $\mathrm{b}^{*}$ (chromaticity blue (-) to yellow (+)) (Cortés and Chiralt, 2008). Viscosity $(\mu)$ of the emulsion and of the $\mathrm{CW}$ were determined by using a rheometer (Brookfield DV-III Ultra (Brookfield Engineering Laboratories, Inc., USA) coupled to a thermostat bath (Brookfield model TC502), controlled temperature at $25^{\circ} \mathrm{C}$, equipped with the RV4 spindle at a rate from 0.01 to $250 \mathrm{rpm}$, reporting viscosity in $\mathrm{cP}$ at a rate of $250 \mathrm{rpm}$ (Mirhosseini et al., 2008). For CP texture a texture analyzer was used (TATA-XT2i, Stable Microsystems Ltd., UK) with a 5-mm 
stainless steel cylindrical probe, in a $25 \mathrm{kgf}$ load cell. A puncture test was applied with a constant probe rate of $1.0 \mathrm{~mm} \cdot \mathrm{s}^{-1}$ and $3 \mathrm{~mm}$ of penetration, determining the maximum force as the mean of the fluctuating peaks on the plateau before reaching $3 \mathrm{~mm}$ of penetration (Prieto et al., 2011).

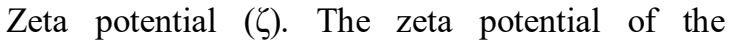
emulsions was determined from the electrophoretic mobility and then by applying Henry's equation, using a Zetasizer Nano ZS90 (Malvern Instruments Ltd., Worcester, UK). To avoid multiple effects of particle dispersion and the presence of air bubbles, the emulsions were diluted with deionized water in an emulsion to water ratio (1:100). Experimental data were reported as the average of the three individual injections (Rezvaniet al., 2012). The stability index through spectral absorption (R) was determined from the ratio of the absorbance at two wavelengths (800 and $400 \mathrm{~nm}$ ) (A $\mathrm{A}_{800} / \mathrm{A}_{400}$ ) (Mirhosseiniet al., 2008), using a UVVisible spectrophotometer (Thermo Scientific Evolution 60). Emulsion samples were diluted in water (1:100) and performed in triplicate per emulsion.

Particle size was determined by using the Mastersizer 3000 (Malvern Instrument Ltd., Worcestershire, UK). The samples were dispersed in $500 \mathrm{ml}$ of distilled water until obtaining a darkening value of $10 \pm 1 \%$. The size distribution was calculated via Mie's theory using the refraction index of 1.52 (Millqvist-Fureby and Smith, 2007) and particle size was reported as percentiles $\mathrm{D}_{10}, \mathrm{D}_{50}$ and $\mathrm{D}_{90}$.

Surface tension $(\sigma)$ was determined through Noüy's ring method (Makri and Doxastakis, 2007) at $15^{\circ} \mathrm{C}$, using a tensiometer (KRUSS K20) with a platinum alloy ring with iridium and surface tension was determined in $\mathrm{mN} / \mathrm{m}$.

Bromatological characterization was carried out of the $\mathrm{CP}$, determining the ash content according to the AOAC 942.05/90 method, fat according to the AOAC 920.39/90 method, proteins according to the AOAC 955.04/90 method and total dietary fiber through the official 985.29 method (AOAC (Association of Official Analytical Chemists), 1990).

The CP and CW yields were conducted by initially weighing the whole coconuts. These were washed and disinfected, then the $\mathrm{CW}$ was removed and the coconuts were scalded in boiling water $\left(\mathrm{T} \approx 96^{\circ} \mathrm{C}\right)$ during 20 min, removing the shell from the $\mathrm{CP}$. The fruit yield was determined from the $\mathrm{kg} \mathrm{CP} / \mathrm{kg}$ coconut and $\mathrm{kg}$ $\mathrm{CW} / \mathrm{kg}$ coconut ratios. The $\mathrm{CP}$ selected was again subjected to a wash process, disinfection, cut into pieces and milling (mill TM32 INOX BRAHER 3HP16801002). Lots of emulsion weighing $3000 \mathrm{~g}$ were separated; initially, the $\mathrm{CP}$ and the $\mathrm{CW}$ were homogenized with potable water in a blender (Osterizer 600 Watts) in position III during $5 \mathrm{~min}$. Then, the mixture was filtered by using a $500-\mu \mathrm{m}$ mesh sieve to separate the fiber from the CM. The fiber obtained was subjected to a drying process at $40^{\circ} \mathrm{C}$ for $48 \mathrm{~h}$ and milling (mill IKA MF 10.1, USA) to reduce particle size and add to the emulsion (Tangsuphoom and Coupland, 2008). Thereafter, the final emulsion was prepared in a homogenizer (Silverson series L5) using the emulsifying head at $10.000 \mathrm{rpm}$ during $10 \mathrm{~min}$, mixing CM, native milled fiber, dairy serum, table salt, $\mathrm{G}_{\text {Xanthan }}$ and TBHQ. A cooling bath was used to keep the temperature from going over $35^{\circ} \mathrm{C}$.

To develop the emulsion formulation, the surface response methodology was used with a central composite experimental design and, thus, establish the principal and combined effects of the independent variables: (A) $\left(\mathrm{CW}+\mathrm{H}_{2} \mathrm{O}\right) / \mathrm{CP}$ ratio $(1.5-2.5)$, (B) $\mathrm{G}_{\text {Xanthan }}(0.25-0.75 \%)$, (C) native fiber $(2.5-7.5 \%)$ and (D) TBHQ (100-200 mg/kg) and dependent variables: $\mathrm{a}_{\mathrm{w}}$, total solids, spectral stability index (R), Peroxide Index (PI), zeta potential $(\zeta)$, surface tension $(\sigma)$, color $\left(L^{*}, a^{*}, b^{*}\right)$, viscosity $(\mu)$ and particle size $\left(D_{10}, D_{50}\right.$ and $\mathrm{D}_{90}$ ), obtaining 21 randomized experiments with five repetitions in the central point. Table 2 describes the experimental design used. The formulation was adjusted in its composition, using the dairy serum as a surfactant with prior determination of its Critical Micelle Concentration (CMC) (Abascal and GarciaFadrique, 2009) and table salt at a concentration of 9 $\mathrm{mMol} / \mathrm{L}$, to increase the repulsive forces and improve the stability of the colloidal system (Dickinson and Stainsby, 1982; Piorkowski and McClements, 2014).

To determine the CMC of the surfactant (dairy serum Instant WCP 80), solutions were prepared at $15^{\circ} \mathrm{C}$ with distilled water to reach the following mass fraction $(\mathrm{p} / \mathrm{p})$ concentrations in triplicate: $0 \%$ as control, $0.05 \%, 0.2 \%, 0.35 \%, 0.5 \%$ and $0.65 \%$. The solutions were homogenized for $5 \mathrm{~min}$ at 300 revolutions per minute (rpm) with an agitator (IKA RW20). They were stored for $48 \mathrm{~h}$ until starting the determinations to observe possible precipitations and surface tension $(\sigma)$ was measured, as already described, by plotting the protein concentration vs. surface tension, determining the CMC (Abascal and Garcia-Fadrique, 2009; Makri and Doxastakis, 2007; González-Tello et al., 2007).

To determine the effect of the independent variables, the multiple regression method was used to predict linear and quadratic coefficients and the interaction of the independent variables in the surface response models, to optimize the proportion of components of the emulsion in terms of the dependent variables. The polynomial model generalized to relate the response to the independent variables was the following:

$\mathrm{Y}=\beta_{0}+\beta_{A} A+\beta_{B} B+\beta_{C} C+\beta_{D} D+\beta_{A}^{2} A^{2}+\beta_{B}^{2} B^{2}+$ $\beta_{C}^{2} C^{2}+\beta_{D}^{2} D^{2}+\beta_{A B} A B+\beta_{C W} C W+\beta_{A D} A D+\beta_{B C} B C+$ $\beta_{B D} B D+\beta_{C D} C D$

where, $\beta_{0}$ is a constant, $\beta_{A}, \beta_{B}, \beta_{C}$ and $\beta_{D}$ is the linear coefficient of each factor; $\beta_{A}{ }^{2}, \beta_{B}{ }^{2}, \beta_{C}{ }^{2}$ and $\beta_{D}{ }^{2}$ is the quadratic coefficient of each factor; $\beta_{A B}, \beta_{C W}, \beta_{A D}, \beta_{B C}$, $\beta_{B D}$ and $\beta_{C D}$ is the product coefficient of the interactions 
of the factors. Adaptation of the models was determined by using the lack-of-fit test and the regression coefficient $\left(\mathrm{R}^{2}\right)$. Additionally, the Analysis of Variance (ANOVA) was performed with $95 \%$ CI. The experimental design matrix, analysis of the results and the optimization procedure were conducted by using Statgraphics Centurion XVI.I software. The experimental data at optimal condition were compared to the adjusted values predicted by the models to verify the regression models.

\section{RESULTS AND DISCUSSION}

Physicochemical composition of coconut: Table 1 presents the mean values plus the standard deviations of the distribution of the parts of the shelled coconut and the physical and physicochemical properties of the CP and $\mathrm{CW}$ with 15 days of harvest, fresh or pseudo-zero.

Note that the edible and usable part reaches approximately $77 \%$ of the whole coconut and where $\mathrm{CW}$ represents an important percentage, which is why its use independent or mixed with $\mathrm{CP}$ results interesting at industrial level. Haseena et al. (2010) found CW content of approximately $251 \mathrm{~mL} /$ coconut, while Appaiah et al. (2015) found a 1:3 water: pulp ratio, with a water content of $117 \pm 42.5 \mathrm{~g} /$ coconut and pulp weight of $330 \pm 19.5 \mathrm{~g}$. Luengwilaiet al.(2014) found a percentage distribution of shelled coconut similar to that in this research: CP (35-50\%), CW (19-28\%) and shell (25-34\%). Other research found that in full maturity, the percentage distribution of coconut was: husk (31-54\%), shell (12-16\%), CP (28-33\%) and CW between 6 and 25\% (Guarte et al., 1996; Siriphanich et al., 2011; Assa et al., 2010). This variability in the results from diverse investigations could be attributable to factors, type of soil, agronomic management, climatology, physiology of the coconut varieties used (non-climatic product), which is promoted by respiration and transpiration and by absorption of CW by the solid endosperm (Siriphanichet al., 2011).

The CP and CW, in general, show high values of $\mathrm{a}_{\mathrm{w}}$ and humidity; while $\mathrm{CW}$ presents low acidity values $(0.041 \pm 0.014)$ corresponding to $\mathrm{pH}=5.7 \pm 0.4$, making them quite susceptible to microbial degradation, which is why after removing the husk these should be stored in refrigeration or freezer. In addition, total solids of the $\mathrm{CP}$ are higher than the $\mathrm{CW}$, at a ratio of $10 / 1$ and provided principally by their fat and fiber contents. Nutritionally, the coconut's fat content represents an important caloric contribution, with a lauric acid content of approximately $50 \%$ and other saturated fatty acids, like caprylic and myristic acids (Marina et al., 2009; Raghavendra and Raghavarao, 2010; Assaet al., 2010). An important fiber contribution is noted in CP, mainly comprised of dietary fiber (Raghavendra et al., 2006; Trinidad et al., 2006; Yalegamaet al., 2013). Tan et al. (2014) reported acidity values for mature CW of $0.061 \pm 0.003 \%$ (expressed as malic acid), $\mathrm{pH} 5.71 \pm 0.10$ and ${ }^{\circ}$ Brix 4.85 \pm 0.17 ; while Prado et al. (2015) reported pH values: 5.01 and $^{\circ}$ Brix: 5.00. Trinidad et al. (2006) reported higher contents of dietary fiber of the coconut fiber: $60.0 \pm 1.0 \%$ (56\% as insoluble fiber and $4 \%$ as soluble), results similar to those reported by Raghavendra et al. (2006) and Yalegamaet al.(2013).

The PI of the CP+CW mix was low, in spite of its high-fat content. However, this parameter can become very critical during its storage, given that it is associated to the degree of oxidation of lipids, fats and oils and could contribute to producing unpleasant flavors that affect negatively the quality of the fruit and its acceptance by consumers (Hornero-Méndez et al., 2001). Raghavendra and Raghavarao (2010) found PI values of $0.82 \pm 0.02$ and $1.46 \pm 0.06 \mathrm{meqH}_{2} \mathrm{O}_{2} / \mathrm{kg}$ oil and acidity index of $0.27 \pm 0.05$ and $0.91 \pm 0.02$ in the coconut oil extracted and a commercial coconut oil, respectively.

Table 1: Physicochemical composition of the unshelled mature coconut fruit

\begin{tabular}{|c|c|c|c|}
\hline Property & Unshelled coconut & $\mathrm{CP}$ & $\mathrm{CW}$ \\
\hline Weight $(\mathrm{kg})$ & $622.3 \pm 61.9$ & & \\
\hline $\mathrm{CP}(\%)$ & $47.1 \pm 3.1$ & ---------- & ---------- \\
\hline $\mathrm{CW}(\%)$ & $30.1 \pm 5.2$ & & \\
\hline Shell (\%) & $26.0 \pm 3.8$ & -------- & ---------- \\
\hline Humidity (\%) & ---------- & $50.4 \pm 5.2$ & $95.0 \pm 1.6$ \\
\hline Acidity index $(\%)^{*}$ & --------- & $0.510 \pm 0.240$ & -------- \\
\hline Acidity $(\%) * *$ & & -------- & $0.041 \pm 0.014$ \\
\hline$a_{w}$ & ---------- & $0.978 \pm 0.005$ & $0.970 \pm 0.030$ \\
\hline${ }^{\circ}$ Brix & ---------- & $6.4 \pm 3.0$ & $3.7 \pm 0.6$ \\
\hline $\mathrm{pH}$ & ---------- & $6.1 \pm 0.2$ & $5.7 \pm 0.4$ \\
\hline$\mu(\mathrm{Cp})$ & --------- & -------- & $0.744 \pm 0.06$ \\
\hline Texture (N) & ---------- & $81.1 \pm 8.3$ & ---------- \\
\hline Density $(\mathrm{g} / \mathrm{mL})$ & ---------- & --------- & $1.015 \pm 0.001$ \\
\hline $\mathrm{L}^{*}$ & --------- & $71.9 \pm 4.3$ & $51.0 \pm 1.5$ \\
\hline$a^{*}$ & ---------- & $-1.1 \pm 0.2$ & $0.3 \pm 1.0$ \\
\hline$b^{*}$ & ---------- & $3.1 \pm 0.8$ & $-1.0 \pm 0.3$ \\
\hline ÍP (meqH ${ }_{2} \mathrm{O}_{2} / \mathrm{kg}$ oil) & --------- & $0.695 \pm 0.340 * * *$ & \\
\hline Protein (\%bh) & ---------- & $3.27 \pm 0.32$ & ---------- \\
\hline Dietary fiber (\%bh) & ---------- & $12.93 \pm 2.47$ & --------- \\
\hline Fat (\%bh) & ---------- & $19.89 \pm 3.03$ & ---------- \\
\hline Ashes (\%bh) & ---------- & $1.08 \pm 0.275$ & ----------- \\
\hline
\end{tabular}

*: Expressed as lauric acid; **: Expressed as malic acid; ***: Mix of $\mathrm{CP}+\mathrm{CW}$ 


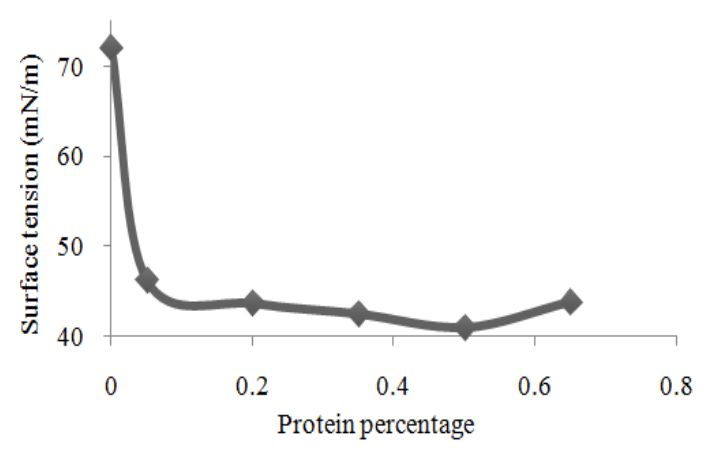

Fig. 1: Surface tension in function of the serum protein concentration

In $\mathrm{CP}$, the acidity index was relatively low $(0.51 \pm 0.24)$; however, it constitutes a measurement of the degree of hydrolysis of the lauric, capric, caproic, caprylic, myristic, oleic, palmitic, stearic, vaccenic and linoleic acids present in the food matrix (Santoso et al., 1996; Waisundara et al., 2007; Assa et al., 2010; Appaiah et al., 2015). The cause of the existence of free fatty acids is the enzyme activity of the lipases. This indicates that free fatty acids have started to oxidize into oxygenated compounds, like-for example-hydroperoxides, because of the action of chemical agents (oxygen, temperature, light, metallic traces) or biochemical agents (microorganisms, lipoxidase enzymes) or the combination of both in function of storage conditions and of the composition of the oil stored; values $\leq 0.8$ are recommended (Kishk and Elsheshetawy, 2013). With respect to color, the L* of the $\mathrm{CP}(71.9 \pm 4.3)$ was higher than that of the $\mathrm{CW}$ (51.0 \pm 1.5$)$, which makes it whiter or clearer and more brilliant on its surface, mainly because of the fat contribution and the fibrous content (Yalegama et al., 2013; Raghavendra et al., 2006); while chromaticities $\mathrm{a}^{*}$ and $\mathrm{b}^{*}$ behaved on the chromatic plane $\mathrm{a}^{*} \mathrm{~b}^{*}$ next to the point (0.0), indicating their a chromaticity (Luengwilai et al., 2014). Some investigations have determined the color of the CP $\left(L^{*}=67, a^{*}=-0.65, b^{*}\right.$ $=1.05)$, results similar to those found in this study (Luengwilai et al., 2014). In CW, according to that reported by Damar (2006), the data show slight changes in values of $\mathrm{L}^{*}=59.74 \pm 0.17, \mathrm{a}^{*}=-1.71 \pm 0.02, \mathrm{~b}^{*}=$ $1.84 \pm 0.02$, in untreated coconut water, stored at $25^{\circ} \mathrm{C}$, presenting a small decrease from week 0 to week 5 and increasing slightly at week 9, showing values and behavior similar to those found in this study (Purkayastha et al., 2012).
The CP texture behaved like a turgid product with an average level of fracturability, mainly of its fibrousporous components in the order of 81.12 $\pm 8.27 \mathrm{~N}$ (Yalegamaet al., 2013; Raghavendra et al., 2006). The CW rheology behaved like a more fluid product with viscosity lower than that of water, due to its composition, mainly constituted by soluble sugars, minerals, proteins and lipids, influencing significantly on it behaving like a Newtonian fluid. These results agree with that reported by Laux et al. (2014), who found equal behavior for cutting rates between 10 and $400 \mathrm{seg}^{-1}$, in all flow tests performed.

Determination of the CMC: It was found that dairy serum proteins have surface activity, upon reducing water surface tension to $\sigma=41 \mathrm{mN} / \mathrm{m}$, which is why it is interesting for its application in foods. The CMC was found, determining the minimum concentration at which we obtain the greatest surface activity by these proteins (González-Tello et al., 2007) (Fig. 1).

This behavior is expected due to the amphiphilic nature of these proteins and their marked surface activity. Figure 1 also shows that at $0.05 \%$ mass fraction concentration the CMC was obtained, with a surface tension value of $\sigma=41 \mathrm{mN} / \mathrm{m}$. As of this concentration, values increase somewhat and, it is estimated, the asymptotic behavior will occur. This phenomenon is normal with these types of materials; it is known that surfactants have a maximum effective concentration, where the liquid's surface is saturated with the material and from there, its excess will generate aggregations known as micelles, which when associating affect characteristics of the solution, like freezing point and conductivity and even forming precipitates (Salager, 2005). These values are similar to those presented by González-Tello et al. (2007) with serum proteins at similar concentrations and to that reported by Abascal and Gracia-Fadrique (2009) with calcium caseinate and sodium solutions, even close values have been found with other proteins, like that extracted from Phaseolus vulgaris in the study by Makri and Doxastakis (2007).

Design of coconut emulsions: Table 2 presents the means values and standard deviations of the dependent variables evaluated according to the statistical design, while Table 3 presents the ANOVA results. Results of the dependent variables were fitted to a second-order

Table 2: Results of the formulation's experimental design and the homogenizing process of coconut-based emulsions

\begin{tabular}{|c|c|c|c|c|c|c|c|c|}
\hline Exp. & $\begin{array}{l}\mathrm{A} \\
\left(\mathrm{CW}+\mathrm{H}_{2} \mathrm{O}\right) / \mathrm{CP}\end{array}$ & $\mathrm{BG}_{\text {Xanthan }}(\%)$ & C Fiber (\%) & $\begin{array}{l}\text { D TBHQ } \\
(\mathrm{mg} / \mathrm{kg})\end{array}$ & $\mathrm{L}^{*}$ & $a^{*}$ & $b^{*}$ & $\mathrm{R}$ \\
\hline 1 & 2.00 & 0.50 & 5.00 & 100 & $66.3 \pm 0.5$ & $3.4 \pm 0.1$ & $6.4 \pm 0.2$ & $0.86 \pm 0.01$ \\
\hline 2 & 1.50 & 0.75 & 7.50 & 200 & $65.1 \pm 3.6$ & $4.1 \pm 0.2$ & $7.0 \pm 0.3$ & $0.86 \pm 0.01$ \\
\hline 3 & 2.00 & 0.50 & 5.00 & 150 & $65.7 \pm 0.1$ & $4.1 \pm 0.2$ & $5.7 \pm 0.2$ & $0.83 \pm 0.01$ \\
\hline 4 & 2.00 & 0.50 & 2.50 & 150 & $67.3 \pm 0.5$ & $4.1 \pm 0.1$ & $5.1 \pm 0.1$ & $0.84 \pm 0.01$ \\
\hline 5 & 2.50 & 0.50 & 5.00 & 150 & $67.9 \pm 0.3$ & $2.6 \pm 0.1$ & $6.8 \pm 0.2$ & $0.83 \pm 0.01$ \\
\hline 6 & 1.50 & 0.50 & 5.00 & 150 & $67.6 \pm 0.5$ & $2.4 \pm 0.2$ & $7.0 \pm 0.2$ & $0.87 \pm 0.00$ \\
\hline 7 & 1.50 & 0.25 & 2.50 & 100 & $70.8 \pm 0.5$ & $1.9 \pm 0.2$ & $6.5 \pm 0.3$ & $0.90 \pm 0.01$ \\
\hline
\end{tabular}


Adv. J. Food Sci. Technol., 14(3): 77-92, 2018

Table 2: Continue

\begin{tabular}{|c|c|c|c|c|c|c|c|c|}
\hline 8 & 2.50 & 0.75 & 7.50 & 100 & $64.5 \pm 1.0$ & $3.7 \pm 0.3$ & $7.7 \pm 0.3$ & $0.86 \pm 0.01$ \\
\hline 9 & 2.00 & 0.50 & 5.00 & 200 & $65.8 \pm 0.5$ & $3.4 \pm 0.2$ & $7.9 \pm 0.7$ & $0.86 \pm 0.00$ \\
\hline 10 & 1.50 & 0.25 & 7.50 & 100 & $65.3 \pm 0.4$ & $3.1 \pm 0.1$ & $8.7 \pm 0.1$ & $0.87 \pm 0.01$ \\
\hline 11 & 2.50 & 0.25 & 2.50 & 200 & $67.6 \pm 0.7$ & $3.4 \pm 0.1$ & $5.8 \pm 0.2$ & $0.85 \pm 0.04$ \\
\hline 12 & 2.00 & 0.75 & 5.00 & 150 & $67.3 \pm 1.4$ & $2.3 \pm 0.1$ & $7.0 \pm 0.4$ & $0.87 \pm 0.00$ \\
\hline 13 & 2.00 & 0.50 & 5.00 & 150 & $71.7 \pm 0.3$ & $2.0 \pm 0.1$ & $6.5 \pm 0.2$ & $0.86 \pm 0.01$ \\
\hline 14 & 2.00 & 0.50 & 5.00 & 150 & $66.8 \pm 0.8$ & $2.6 \pm 0.2$ & $7.5 \pm 0.3$ & $0.86 \pm 0.00$ \\
\hline 15 & 2.50 & 0.25 & 7.50 & 200 & $67.6 \pm 0.2$ & $2.5 \pm 0.1$ & $6.8 \pm 0.3$ & $0.84 \pm 0.01$ \\
\hline 16 & 2.00 & 0.50 & 5.00 & 150 & $67.8 \pm 0.4$ & $2.0 \pm 0.1$ & $6.9 \pm 0.3$ & $0.85 \pm 0.01$ \\
\hline 17 & 2.00 & 0.50 & 5.00 & 150 & $68.8 \pm 1.0$ & $1.8 \pm 0.3$ & $6.8 \pm 0.4$ & $0.87 \pm 0.01$ \\
\hline 18 & 2.00 & 0.50 & 7.50 & 150 & $65.6 \pm 0.9$ & $3.1 \pm 0.2$ & $7.6 \pm 0.4$ & $0.87 \pm 0.01$ \\
\hline 19 & 2.00 & 0.25 & 5.00 & 150 & $66.9 \pm 0.4$ & $2.7 \pm 0.1$ & $7.5 \pm 0.2$ & $0.85 \pm 0.01$ \\
\hline 20 & 1.50 & 0.75 & 2.50 & 200 & $69.4 \pm 0.4$ & $1.8 \pm 0.1$ & $7.1 \pm 0.3$ & $0.88 \pm 0.00$ \\
\hline 21 & 2.50 & 0.75 & 2.50 & 100 & $68.8 \pm 0.4$ & $2.3 \pm 0.2$ & $6.8 \pm 0.3$ & $0.86 \pm 0.01$ \\
\hline Exp. & $\mu(\mathrm{cP})$ & $\mathrm{PI}\left(\mathrm{meqH}_{2} \mathrm{O}_{2} / \mathrm{kg}\right)$ & $\mathrm{D}_{10}(\mu \mathrm{m})$ & $\mathrm{D}_{50}(\mu \mathrm{m})$ & $\mathrm{D}_{90}(\mu \mathrm{m})$ & $\zeta(\mu \mathrm{m})$ & aw $(\mathrm{mV})$ & TS \\
\hline 1 & $705.2 \pm 22.6$ & $0.14 \pm 0.07$ & $3.1 \pm 0.1$ & $50.3 \pm 10.9$ & $537.2 \pm 48.6$ & $-52.2 \pm 1.6$ & $0.980 \pm 0.00$ & $19.6 \pm 0.1$ \\
\hline 2 & $1530.7 \pm 40.3$ & $0.10 \pm 0.03$ & $3.2 \pm 0.3$ & $127.0 \pm 38.0$ & $648.4 \pm 49.1$ & $-53.3 \pm 1.8$ & $0.982 \pm 0.01$ & $24.6 \pm 0.2$ \\
\hline 3 & $610.6 \pm 6.7$ & $0.07 \pm 0.03$ & $2.4 \pm 0.1$ & $93.3 \pm 37.5$ & $574.7 \pm 34.0$ & $-55.6 \pm 1.8$ & $0.987 \pm 0.00$ & $19.1 \pm 0.1$ \\
\hline 4 & $369.4 \pm 2.9$ & $0.06 \pm 0.01$ & $1.9 \pm 0.5$ & $11.9 \pm 3.0$ & $481.8 \pm 36.7$ & $-54.7 \pm 1.8$ & $0.987 \pm 0.00$ & $17.1 \pm 0.2$ \\
\hline 5 & $732.3 \pm 14.6$ & $0.08 \pm 0.04$ & $2.1 \pm 0.3$ & $157.7 \pm 73.4$ & $464.1 \pm 99.0$ & $-45.4 \pm 6.5$ & $0.992 \pm 0.00$ & $16.1 \pm 0.2$ \\
\hline 6 & $746.5 \pm 11.2$ & $0.04 \pm 0.03$ & $4.7 \pm 0.4$ & $139.5 \pm 48.5$ & $546.8 \pm 54.7$ & $-47.1 \pm 1.6$ & $0.984 \pm 0.00$ & $19.1 \pm 0.2$ \\
\hline 7 & $241.1 \pm 13.1$ & $0.05 \pm 0.03$ & $8.1 \pm 3.1$ & $58.2 \pm 17.7$ & $566.9 \pm 83.3$ & $-47.9 \pm 1.5$ & $0.987 \pm 0.00$ & $17.0 \pm 0.1$ \\
\hline 8 & $2252.7 \pm 21.9$ & $0.07 \pm 0.02$ & $4.0 \pm 0.6$ & $394.7 \pm 52.1$ & $920.6 \pm 287.7$ & $-47.3 \pm 1.0$ & $0.987 \pm 0.00$ & $21.0 \pm 0.2$ \\
\hline 9 & $840.3 \pm 10.8$ & $0.04 \pm 0.01$ & $3.2 \pm 0.2$ & $222.2 \pm 36.4$ & $601.4 \pm 47.5$ & $-48.6 \pm 1.7$ & $0.986 \pm 0.00$ & $20.5 \pm 0.1$ \\
\hline 10 & $1503.3 \pm 96.0$ & $0.06 \pm 0.02$ & $26.1 \pm 14.0$ & $302.1 \pm 17.1$ & $666.8 \pm 43.4$ & $-44.2 \pm 1.2$ & $0.985 \pm 0.00$ & $25.2 \pm 0.5$ \\
\hline 11 & $309.9 \pm 4.0$ & $0.11 \pm 0.04$ & $3.0 \pm 0.2$ & $10.1 \pm 1.5$ & $383.8 \pm 99.9$ & $-44.7 \pm 3.3$ & $0.986 \pm 0.00$ & $16.1 \pm 0.2$ \\
\hline 12 & $1054.3 \pm 30.1$ & $0.06 \pm 0.03$ & $2.1 \pm 0.2$ & $164.8 \pm 55.5$ & $533.2 \pm 112.0$ & $-45.4 \pm 1.3$ & $0.984 \pm 0.00$ & $20.2 \pm 0.2$ \\
\hline 13 & $587.6 \pm 21.5$ & $0.03 \pm 0.03$ & $2.4 \pm 0.2$ & $234.8 \pm 46.3$ & $631.6 \pm 55.4$ & $-48.6 \pm 1.4$ & $0.986 \pm 0.00$ & $19.2 \pm 0.1$ \\
\hline 14 & $679.5 \pm 21.1$ & $0.12 \pm 0.03$ & $2.4 \pm 0.4$ & $155.2 \pm 77.7$ & $605.8 \pm 135.4$ & $-44.1 \pm 1.4$ & $0.985 \pm 0.00$ & $21.6 \pm 0.1$ \\
\hline 15 & $268.8 \pm 5.8$ & $0.09 \pm 0.04$ & $2.5 \pm 0.2$ & $81.9 \pm 47.0$ & $621.1 \pm 51.3$ & $-45.4 \pm 2.1$ & $0.982 \pm 0.00$ & $17.8 \pm 0.1$ \\
\hline 16 & $403.7 \pm 12.8$ & $0.06 \pm 0.03$ & $1.6 \pm 0.1$ & $58.1 \pm 21.0$ & $513.7 \pm 46.4$ & $-42.8 \pm 1.0$ & $0.985 \pm 0.00$ & $18.7 \pm 0.2$ \\
\hline 17 & $406.4 \pm 20.9$ & $0.04 \pm 0.03$ & $1.7 \pm 0.1$ & $126.1 \pm 65.4$ & $624.0 \pm 99.6$ & $-41.6 \pm 0.6$ & $0.989 \pm 0.00$ & $20.1 \pm 0.1$ \\
\hline 18 & $1360.0 \pm 85.4$ & $0.09 \pm 0.02$ & $3.0 \pm 0.2$ & $249.2 \pm 38.8$ & $600.9 \pm 57.5$ & $-45.9 \pm 1.4$ & $0.991 \pm 0.00$ & $23.0 \pm 0.2$ \\
\hline 19 & $298.0 \pm 12.2$ & $0.05 \pm 0.04$ & $2.5 \pm 0.2$ & $239.7 \pm 85.5$ & $689.4 \pm 95.3$ & $-39.1 \pm 2.8$ & $0.988 \pm 0.00$ & $19.7 \pm 0.2$ \\
\hline 20 & $857.3 \pm 52.0$ & $0.09 \pm 0.02$ & $1.9 \pm 0.2$ & $136.5 \pm 78.1$ & $647.9 \pm 147.1$ & $-44.2 \pm 1.8$ & $0.992 \pm 0.00$ & $18.5 \pm 0.1$ \\
\hline 21 & $531.3 \pm 14.4$ & $0.18 \pm 0.02$ & $1.6 \pm 0.1$ & $91.9 \pm 36.9$ & $802.9 \pm 90.0$ & $-45.2 \pm 2.1$ & $0.972 \pm 0.01$ & $13.6 \pm 0.1$ \\
\hline
\end{tabular}

Table 3: ANOVA (p-values) for surface response models

\begin{tabular}{|c|c|c|c|c|c|c|c|c|}
\hline \multirow[b]{2}{*}{ Variables } & \multicolumn{4}{|c|}{ Principal effects } & \multicolumn{4}{|c|}{ Quadratic effects } \\
\hline & A & B & $\mathrm{C}$ & D & $\mathrm{A}^{2}$ & $\mathrm{~B}^{2}$ & $\mathrm{C}^{2}$ & $\mathrm{D}^{2}$ \\
\hline$\overline{\mathrm{L}^{*}}$ & $0.0000^{*}$ & 0.9036 & $0.0220^{*}$ & 0.8739 & $0.0148 *$ & 0.5559 & 0.1724 & $0.0236^{*}$ \\
\hline$a^{*}$ & $0.0000^{*}$ & 0.1945 & 0.0542 & 0.3675 & $0.0000 *$ & $0.0000 *$ & $0.0000 *$ & $0.0000^{*}$ \\
\hline $\mathrm{b}^{*}$ & 0.0834 & $0.0000 *$ & $0.0000 *$ & 0.3314 & 0.6763 & $0.0000 *$ & $0.0000 *$ & $0.0000^{*}$ \\
\hline $\mathrm{R}$ & 0.7768 & 0.6701 & 0.1310 & 0.1161 & 0.3089 & 0.1615 & 0.5550 & 0.0726 \\
\hline$\mu$ & $0.0000 *$ & $0.0000 *$ & $0.0172 *$ & 0.5493 & 0.0863 & 0.9429 & $0.0000 *$ & $0.0000^{*}$ \\
\hline PI & 0.1341 & $0.0103 *$ & 0.9708 & 0.0736 & 0.9951 & 0.5578 & 0.3366 & $0.0446^{*}$ \\
\hline $\mathrm{D}_{10}$ & $0.0000^{*}$ & $0.000^{*}$ & $0.0000 *$ & $0.0000^{*}$ & $0.0193 *$ & 0.4071 & 0.3145 & $0.0430^{*}$ \\
\hline $\mathrm{D}_{50}$ & 0.5576 & $0.0000^{*}$ & $0.0000^{*}$ & $0.0000^{*}$ & 0.7829 & $0.0000 *$ & 0.0925 & 0.2158 \\
\hline $\mathrm{D}_{90}$ & 0.0505 & $0.0000 *$ & 0.6537 & $0.0000^{*}$ & 0.2154 & $0.0000 *$ & 0.7491 & 0.1253 \\
\hline $\mathrm{Z}$ & 0.3405 & $0.0000 *$ & $0.0000 *$ & $0.0000^{*}$ & 0.1461 & $0.0000 *$ & $0.0000 *$ & $0.0000^{*}$ \\
\hline$a_{w}$ & 0.3605 & $0.0126^{*}$ & 0.0772 & $0.0314^{*}$ & 0.4165 & 0.3126 & 0.1849 & $0.0000^{*}$ \\
\hline \multirow[t]{2}{*}{$\underline{T S}$} & $0.0000^{*}$ & $0.0000 *$ & $0.0000^{*}$ & 0.2981 & $0.0000 *$ & $0.0409 *$ & $0.0210 *$ & $0.0345^{*}$ \\
\hline & \multicolumn{6}{|c|}{ Effects of the interaction } & & \\
\hline Variables & $\mathrm{AB}$ & $\mathrm{AC}$ & $\mathrm{AD}$ & $\mathrm{BC}$ & $\mathrm{BD}$ & $\mathrm{CD}$ & & \\
\hline $\mathrm{L}^{*}$ & 0.3904 & $0.0000^{*}$ & 0.1321 & $0.0345^{*}$ & 0.2622 & $0.0000 *$ & & \\
\hline$a^{*}$ & 0.6333 & $0.0000^{*}$ & $0.0009^{*}$ & $0.0000^{*}$ & 0.8573 & $0.0213^{*}$ & & \\
\hline$b^{*}$ & $0.0000 *$ & 0.6104 & $0.0000 *$ & $0.0000^{*}$ & 0.3222 & $0.0000 *$ & & \\
\hline $\mathrm{R}$ & 0.5116 & 0.1534 & 0.3463 & 0.4590 & 0.1666 & 0.6243 & & \\
\hline$\mu$ & $0.0000^{*}$ & 0.1101 & 0.6171 & $0.0000^{*}$ & $0.0476^{*}$ & $0.0000 *$ & & \\
\hline PI & $0.0000 *$ & $0.0133 *$ & 0.5969 & 0.1250 & 0.9920 & 0.0901 & & \\
\hline$D_{10}$ & $0.0000 *$ & $0.0000 *$ & $0.0000 *$ & $0.0000^{*}$ & $0.0143 *$ & $0.0000 *$ & & \\
\hline$D_{50}$ & $0.0000 *$ & $0.0201 *$ & $0.0000 *$ & 0.6555 & 0.3469 & $0.0000 *$ & & \\
\hline $\mathrm{D}_{90}$ & $0.0000 *$ & $0.0151 *$ & $0.0000 *$ & $0.0362 *$ & $0.0238^{*}$ & 0.8448 & & \\
\hline Z & $0.0306 *$ & 0.4558 & $0.0359 *$ & $0.0001 *$ & 0.9901 & $0.0000 *$ & & \\
\hline$a_{w}$ & 0.3407 & $0.0000^{*}$ & 0.6234 & $0.0365^{*}$ & $0.0000 *$ & $0.0000 *$ & & \\
\hline TS & 0.1336 & $0.0000 *$ & 0.8323 & $0.0000^{*}$ & $0.0293 *$ & $0.0000 *$ & & \\
\hline
\end{tabular}

* Significant $(\mathrm{p}<0.05)$ 
polynomial regression model and the ANOVA showed that the surface response models were significant with 95\% $\mathrm{CI}$ for all the regression equations

Water activity ( $\left.\mathbf{a}_{\mathbf{w}}\right)$ and total solids: Figure 2 presents the surface response plots of the $a_{w}$ and the TS in function of the independent variables. The $\mathrm{a}_{\mathrm{w}}$ showed significant differences $(p<0.05)$ with respect to $G_{\text {Xanthan }}$ and to the TBHQ content; as well as with respect to the $\mathrm{G}_{\text {Xanthan-fiber percentage interaction. The TS presented }}$ significant differences $(p<0.05)$ with respect to the $\mathrm{Gx}_{\text {anthan, fiber percentaje and TBHQ quadratic }}$ interactions and with the $\mathrm{G}_{\mathrm{Xanthan}} \mathrm{TBHQ}$ interaction.

The emulsion values of $\mathrm{a}_{\mathrm{w}}$ showed little fluctuation (0.972 $\pm 0.01-0.992 \pm 0.00)$, conserving high values that denote a favorable condition for microbiological growth and deterioration reactions, like lipid oxidation and
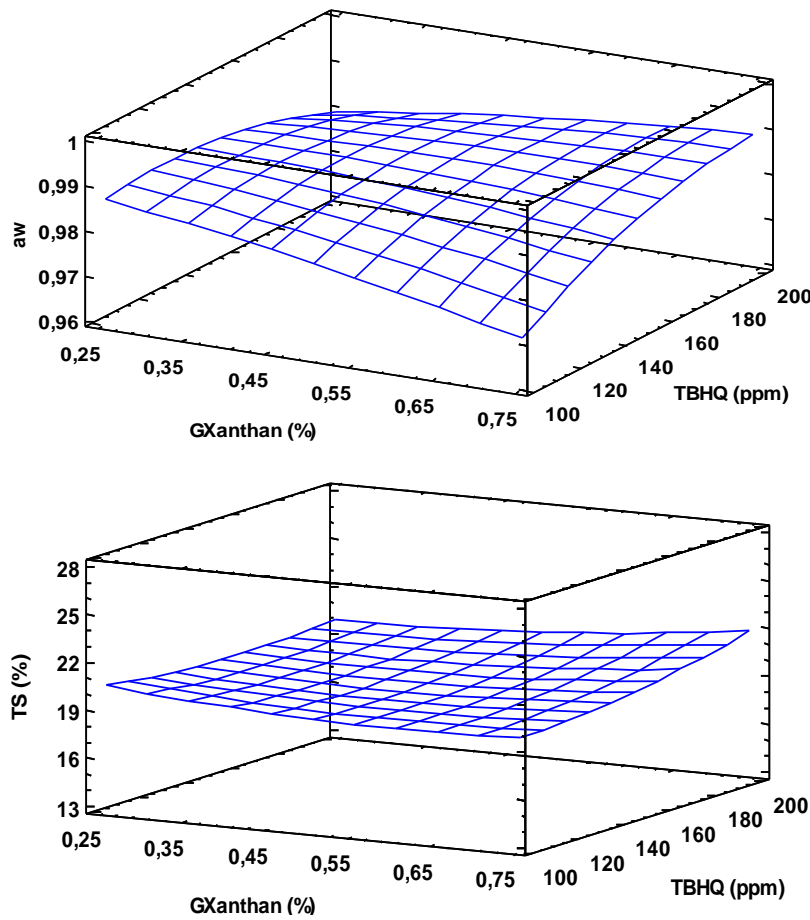

non-enzymatic browning (Appaiah et al., 2015; Haseena et al., 2010).

The $\mathrm{a}_{\mathrm{w}}$ had an inversely proportional effect with respect to $G_{X a n t h a n}$, while TBHQ had an opposite effect

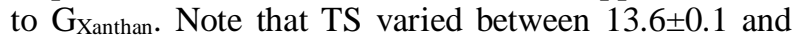
$25.2 \pm 0.5 \%$, highlighting their increase due to the effect of increased fiber percentage, which is favorable in spray drying processes, given that it improves the productive and energetic yield (Phisut, 2012; Khuenpet et al., 2016; Tontul and Topuz, 2017).

Color: Figure 3 plots the $\mathrm{L}^{*}$ surface response in function of the independent variables. The color of the emulsions $\left(\mathrm{L}^{*}, \mathrm{a}^{*}\right.$ and $\left.\mathrm{b}^{*}\right)$ revealed the influence of the linear effects of the independent variables considered and their linear and quadratic interactions, varying the averages of the ranges (71.7-64.5), (4.1-1.8), (8.7-5.1), respectively. According to these results, changes on the
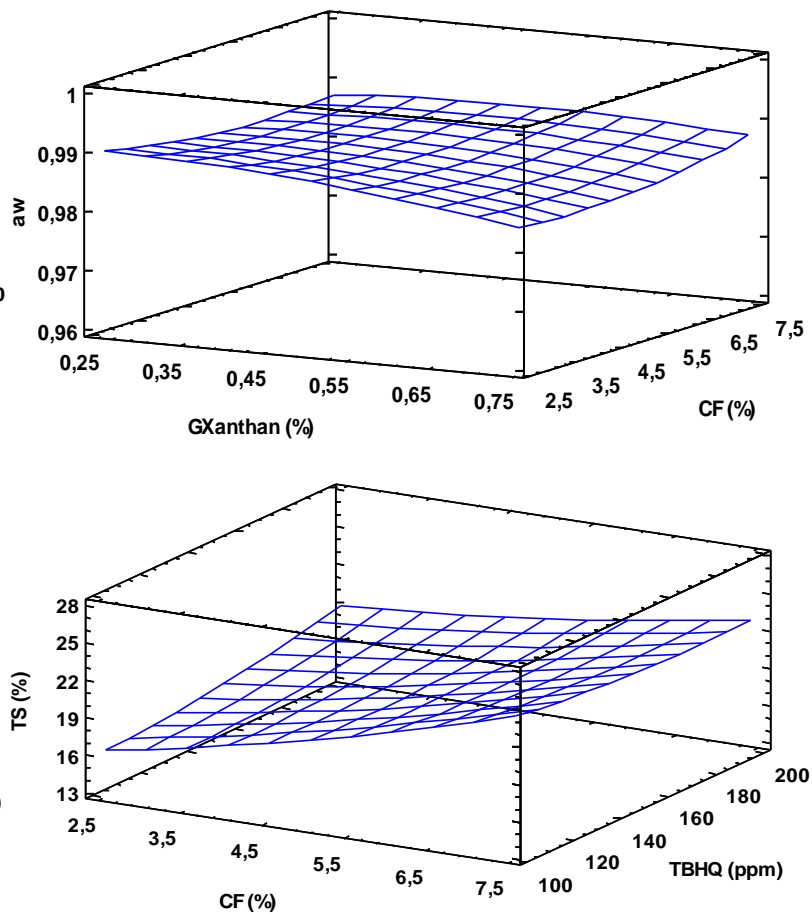

Fig. 2: Surface response plots of the $a_{w}$ and the total solids in function of the independent variables

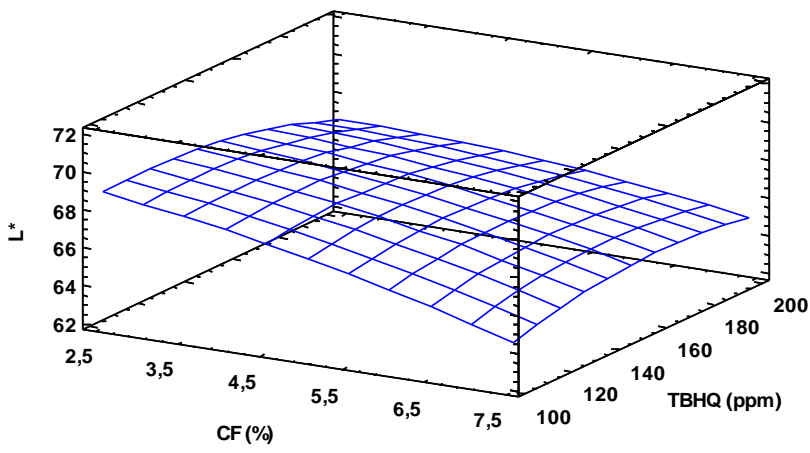

Fig. 3: Graphics of the $\mathrm{L}^{*}$ response surface

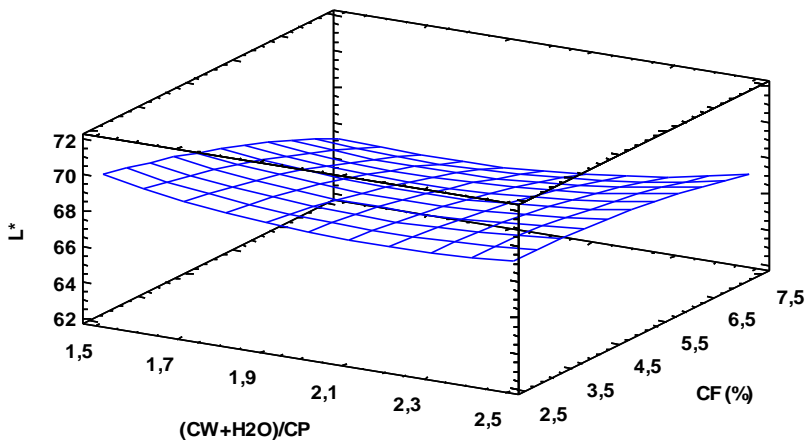


$a^{*} b^{*}$ chromatic planeare minimal or inappreciable to the human eye, given that they are in the grey zone (achromatic zone) (Gilabert, 1998; Alvarado and Aguilera, 2001), which is why $\mathrm{L}^{*}$ represents the most important color variable or control variable.

The ANOVA presented statistically significant differences $(p<0.05)$ in $L^{*}$ with respect to the fiber percentage; additionally, due to the effect of the quadratic interactions of the $\left(\mathrm{CW}+\mathrm{H}_{2} \mathrm{O}\right) / \mathrm{CP}$ ration and of the antioxidant (TBHQ) and because of the $\mathrm{G}_{\text {Xanthan }}{ }^{-}$ fiber percentage linear interaction. The $\mathrm{L}^{*}$ present a decreasing trend with the increased fiber percentage present, perceiving less clear emulsions.

This could be attributed to diverse factors, like the greater presence of the fiber generates a lower reflection of light (Prieto et al., 2011) and loss of translucency of the emulsion, permitting the passage of light-although in a diffuse manner ( $\mathrm{Ng}$ et al., 2014). Furthermore, higher fiber content increases the content of brown pigment of the endocarp (zone adjacent to the husk).

A decrease of $\mathrm{L}^{*}$ occurs at low $\left(\mathrm{CW}+\mathrm{H}_{2} \mathrm{O}\right) / \mathrm{CP}$ ratios, which could be attributed to higher $\mathrm{CP}$ content in the formulation, corresponding to a higher contribution of fiber and oil contained in the formulation. Under these conditions and bearing in mind the addition of dry fiber and increased temperature $\left(20 \rightarrow 35^{\circ} \mathrm{C}\right)$ and air content during the homogenizing process, the emulsions are perceived darker. This phenomenon, as a whole, is associated to the higher content of solids, lipid oxidation with the production of hydro-peroxides and free radicals (Ochoa-Velasco et al., 2014; Kuhn and Cunha, 2012), possible enzymatic browning due to the presence of peroxidase and polyphenol oxidase enzymes (Borda, 2011) and non-enzymatic (Prieto et al., 2011). In addition, the positive fiber percentageTBHQ interaction enhances diminished $\mathrm{L}^{*}$ at high fiber and TBHQ contents.

Some researchers, as described ahead, have evaluated the addition of dehydrated $\mathrm{CP}\left(60-80^{\circ} \mathrm{C}\right)$ in the final product, producing a decrease of $\mathrm{L}^{*}$ between 66 and 68, attributing the biggest cause of darkening to the Maillard reaction, given the flavor and odor of the final product (Prieto et al., 2011). Other investigations report darkening of the pulp, emulsions and dry fiber due mainly to the process' increased temperature that favors the Maillard reaction, changing color from a pale target to brown and without registering an important loss of quality (Guarte et al., 1996; Chiewchan et al., 2006). Tipvarakarnkoon et al. (2010) report $\mathrm{L}^{*}$ : $81.72 \pm 1.50$; a*: $-0.66 \pm 0.18, b^{*}: 2.1 \pm 0.73$ values in "commercial coconut milk"; while in "coconut milk" elaborated with diverse types of acacia gum, with and without Tween 60, with and without $G_{X a n t h a n}$ and/or guar gum, they showed significant differences principally in $\mathrm{L}^{*}$, but did not highlight notable changes in chromaticities $a^{*}$ and $b^{*}$, results quite similar to those obtained in this research.
In general, changes in the optical properties of the coconut emulsions are mainly determined by their composition, temperature, relative refraction index, concentration and size distribution of the oil drops and dispersed particles, which have important implications in the development of transparent or opaque beverages (Piorkowski and McClements, 2014).

Physicochemical stability of the colloidal system: Figure 4 presents the surface response plot of parameters associated to the physicochemical stability of the emulsion: $\zeta, \mu, \mathrm{D}_{10}, \mathrm{D}_{50}, \mathrm{D}_{90}$ and $\sigma$ in function of the independent variables.

$\mathbf{R}$ index and particle size: The stability index, $R$, did not show significant differences $(\mathrm{p}<0.05)$ with respect to the independent variables, given that its variation range was low (0.83-0.90). The $\mathrm{R}$ index is based on light dispersion properties. It is related to the mean particle size (Mirhosseini et al., 2008; Homayoonfal et al., 2015), which is why it is considered that these values were high. This was evidenced in the $\mathrm{D}_{10}, \mathrm{D}_{50}$ and $D_{90}$ percentiles that were big and fluctuating: $D_{10}$ $(1.62 \pm 0.10 \quad-26.08 \pm 14.00 \mu \mathrm{m}), \quad \mathrm{D}_{50} \quad(11.90 \pm 2.96-$ $302.11 \pm 17.01 \mu \mathrm{m})$ and $\mathrm{D}_{90} \quad(383.78 \pm 99.86-$ $920.56 \pm 287.75 \mu \mathrm{m})$, which could favor phase separation and identify the need for other mechanisms for their stabilization.

The $\mathrm{D}_{10}$ percentile presented significant differences $(\mathrm{p}<0.05)$ with respect to las quadratic interactions of the $\left(\mathrm{CW}+\mathrm{H}_{2} \mathrm{O}\right) / \mathrm{CP}$ ratio and the TBHQ, in addition to the $\mathrm{G}_{\text {Xanthan }}-\mathrm{TBHQ}$ interaction, while the $\mathrm{D}_{50}$ percentile was significant with the $\left(\mathrm{CW}+\mathrm{H}_{2} \mathrm{O}\right) / \mathrm{CP}$-fiber percentage interaction. The $\mathrm{D}_{90}$ percentile showed significant differences $(p<0.05)$ with respect to the linear interactions of the $\left(\mathrm{CW}+\mathrm{H}_{2} \mathrm{O}\right) / \mathrm{CP}$-fiber percentage ratio, $\mathrm{G}_{\text {Xanthan }}$-fiber percentage and $\mathrm{G}_{\text {Xanthan }}-\mathrm{TBHQ}$. Mainly highlighted is the increase in the $\mathrm{D}_{10}$ percentile to high contents of fiber and low $\left(\mathrm{CW}+\mathrm{H}_{2} \mathrm{O}\right) / \mathrm{CP}$ ratio, besides-contrary to expected-with decreased $\mathrm{G}_{\text {Xanthan }}$. In addition, the increase in $\mathrm{D}_{50}$ is produced with increased fiber percentage and the increase in $\mathrm{D}_{90}$ is produced by increased $\mathrm{G}_{\text {Xanthan }}$ and fiber percentage.

In general, the percentile differences can be attributed mainly to the complexity of the raw matter regarding fruit maturity and composition (oil fiber, protein, others), to the $\mathrm{G}_{\text {Xanthan }}$ composition that correlates directly with viscosity and its shear effect and particle disintegration, acting to reduce the size of the oily drops and of the high-hardness coconut fiber (Raghavendra et al., 2006). It is considered that among the particle size distribution, the smallest are associated to drops of oil, while the biggest are associated to the suspended fibers in the emulsion (Wallecan et al., 2015). This behavior is very similar to that reported by Homayoonfal et al. (2015) andTipvarakarnkoon et al. (2010), which report that the intensity of the shear 
Adv. J. Food Sci. Technol., 14(3): 77-92, 2018
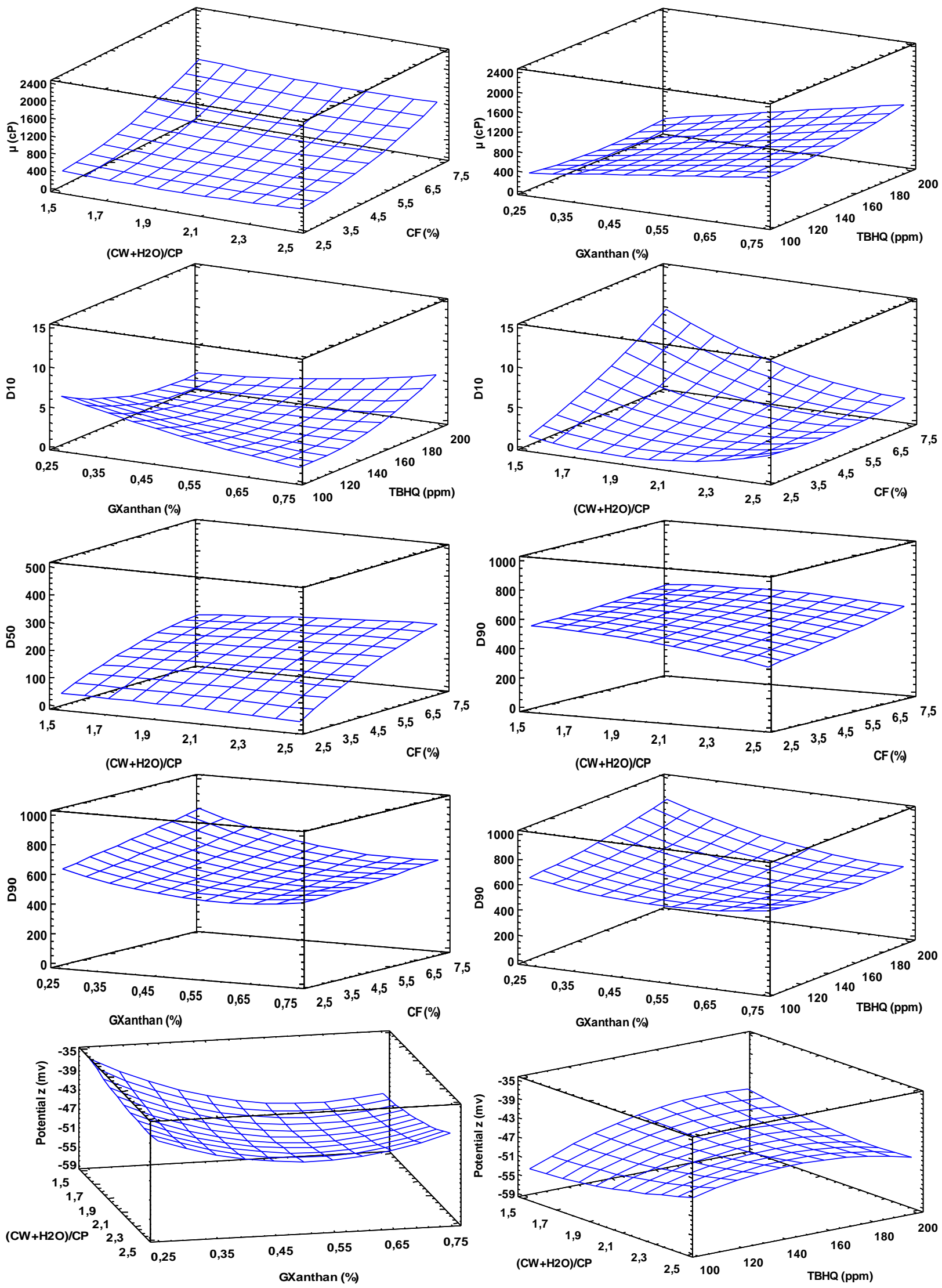

Fig. 4: Surface response plots of parameters associated to the stability of the emulsion in function of the independent variables 
force, turbulence and cavitation created by the homogenizer determine the mean particle size and increased homogenization time leads to a higher temperature, provoking decreased interfacial tension and viscosity (Anarjan et al., 2010).

Viscosity: The $\mu$ presented significant differences $(\mathrm{p}<0.05)$ with respect to fiber percentage and to the $\mathrm{G}_{\text {Xanthan }}-\mathrm{TBHQ}$ linear interaction, highlighting a trend to increase $\mu$ with increased $G_{\text {Xanthan }}$ content, which can bind water subjecting itself to a double helix conformational transition of an aggregate complex through hydrogen bonds and polymer entanglement (Jayme et al., 1999; Niu et al., 2017), which finally modifies the rheological properties of the continuous phase and favoring system stability by reducing the mobility of the colloidal system's particles and delaying phase separation (Jayme et al., 1999; Piorkowski and McClements, 2014; Niu et al., 2017). The increased content of suspended solids provided by the added fiber, also favored increased viscosity; however, given the variability and large particle sizes found in the $\mathrm{D}_{10}$, $\mathrm{D}_{50}$ and $\mathrm{D}_{90}$ percentiles does not favor system stability.

Some authors have reported that "coconut milk" exhibits pseudo-plastic behavior (Vitali et al., 1985; Simuang et al., 2004; Chiewchan et al., 2006), which is affected by the presence of stabilizers and fat content (Simuang et al., 2004; Tangsuphoom and Coupland, 2005; Chiewchan et al., 2006; Peamprasart and Chiewchan, 2006; Tipvarakarnkoon et al., 2010; Ng et al., 2014;:Li and Nie, 2016; Piorkowski and McClements, 2014). Other research on "coconut milk" have used Montanox 60 (emulsifier) and carboxymethylcellulose, reporting increased $\mu$ of the continuous phase (Jirapeangtong et al., 2008; Tipvarakarnkoon et al., 2010) and favoring its stability upon delaying phase separation or reducing the particle aggregation kinetics (McClements, 2004a, 2004b; Klinkesorn et al., 2004; Phungamngoen et al., 2004; Mantzouridou et al., 2012). The aforementioned coincides with that reported by Mirhosseini et al. (2008), with orange beverage emulsions containing high concentrations of gum arabic and $\mathrm{G}_{\text {Xanthan, }}$ exhibiting high apparent viscosity and relatively medium drop size.

The $\mu$ showed the tendency to increase with increased fiber content, which has been reported by diverse authors (Pelegrine et al., 2002; Valencia et al., 2004; Elleuch et al., 2011; Castro et al., 2013). Additionally, it is considered that homogenization produces changes of particle properties, influencing on the rheology of the colloidal system (Elleuch et al., 2011; Castro et al., 2013). These changes of $\mu$ can be higher in some fibers than in others, given the difference of the type of pectin present in the cell structure and its hardness, which makes the homogenization response different. Furthermore, the way groups of cells interrupt through the cell wall or through the middle lamella seems to have an effect on the rheological properties of the suspensions (Day et al., 2010; López-Sánchez et al., 2011; Elleuch et al., 2011; Castro et al., 2013).

Potential- $\zeta$ : The potential- $\zeta$ showed significant differences $(\mathrm{p}<0.05)$ with respect to the $\left(\mathrm{CW}+\mathrm{H}_{2} \mathrm{O}\right) / \mathrm{CP}-$ $\mathrm{G}_{\text {Xanthan }}$ and $\left(\mathrm{CW}+\mathrm{H}_{2} \mathrm{O}\right) / \mathrm{CP}-\mathrm{TBHQ}$ interactions, which derives into a curvature behavior on the response surface. The influence of the $\mathrm{G}_{\text {Xanthan }}$ by being an anionic polysaccharide, due to the carboxyl groups present from the lateral chains (Piorkowski and McClements, 2014), contributed to increasing the repulsive forces in the proximities of the co-ion layer, making their potential- $\zeta$ more negative with the increase of the hydrocolloid in the formulation. The magnitude of the polysaccharide's electric charge depends on $\mathrm{pH}$ in relation to the $\mathrm{pKa}$ value (Jayme et al., 1999; Mirhosseiniet al., 2008; Piorkowski and McClements, 2014). Due to this, this polysaccharide will have a higher contribution of negative electric charge, given that the $\mathrm{pH}$ values of the emulsions (5.935 \pm 0.212$)$ are above the pKa value (2.00-2.87) (Souza and Garcia-Rojas, 2017; Mirhosseini et al., 2008; Niu et al., 2017). Proteins are negative above the isoelectric point ( $\mathrm{pI}=\sim 4$ ) (Thaiphanit et al., 2016), which favored the values of potential- $\zeta$ being more negative.

The potential $\zeta$ presented a variation between $39.1 \pm 2.8$ and $-55.6 \pm 1.8 \mathrm{mV}$, which favors the emulsion's thermodynamic stability, given that it denotes a good repulsive interaction or repulsive forces among colloid particles (Estevinho et al., 2014; Mirhosseini et al., 2008; Rezvani et al., 2012). Coconut is rich in mineral salts, like potassium, sodium, phosphorus, iron, copper and chlorine (Appaiah et al., 2015; Siriphanich et al.,2011; Tan et al., 2014; Jayalekshmy et al., 1986; Piorkowski and McClements, 2014), which when dissociating produce an important ionic force in the continuous phase, whose ions are strongly adsorbed in the particle interface, whichlikewise-have ionizable groups of opposite charge, producing or resulting in a strongly adsorbed co-ion layer of negative charge on the particle interface. This situation also produces an electrical potential outside this adsorbed layer (Stern layer) associated to the zeta potential found (Malvern Instruments, 2004); besides contributing to the formation of a second co-ion diffuse layer distributed in the dissolution next to the interface. Both layers form the known ion double layer or Debye length (к-1) (Jayme et al., 1999; Piorkowski and McClements, 2014; Niu et al., 2017).

The bibliographic review shows an important contribution of the electrostatic forces in stabilizing food colloidal systems: $\approx-16 \mathrm{mV}$ in "homogenized coconut milk" without fiber and with active surface stabilizers added (Tangsuphoom and Coupland, 2009); between -17.1 and $-13.8 \mathrm{mV}$ in dressings with orange 

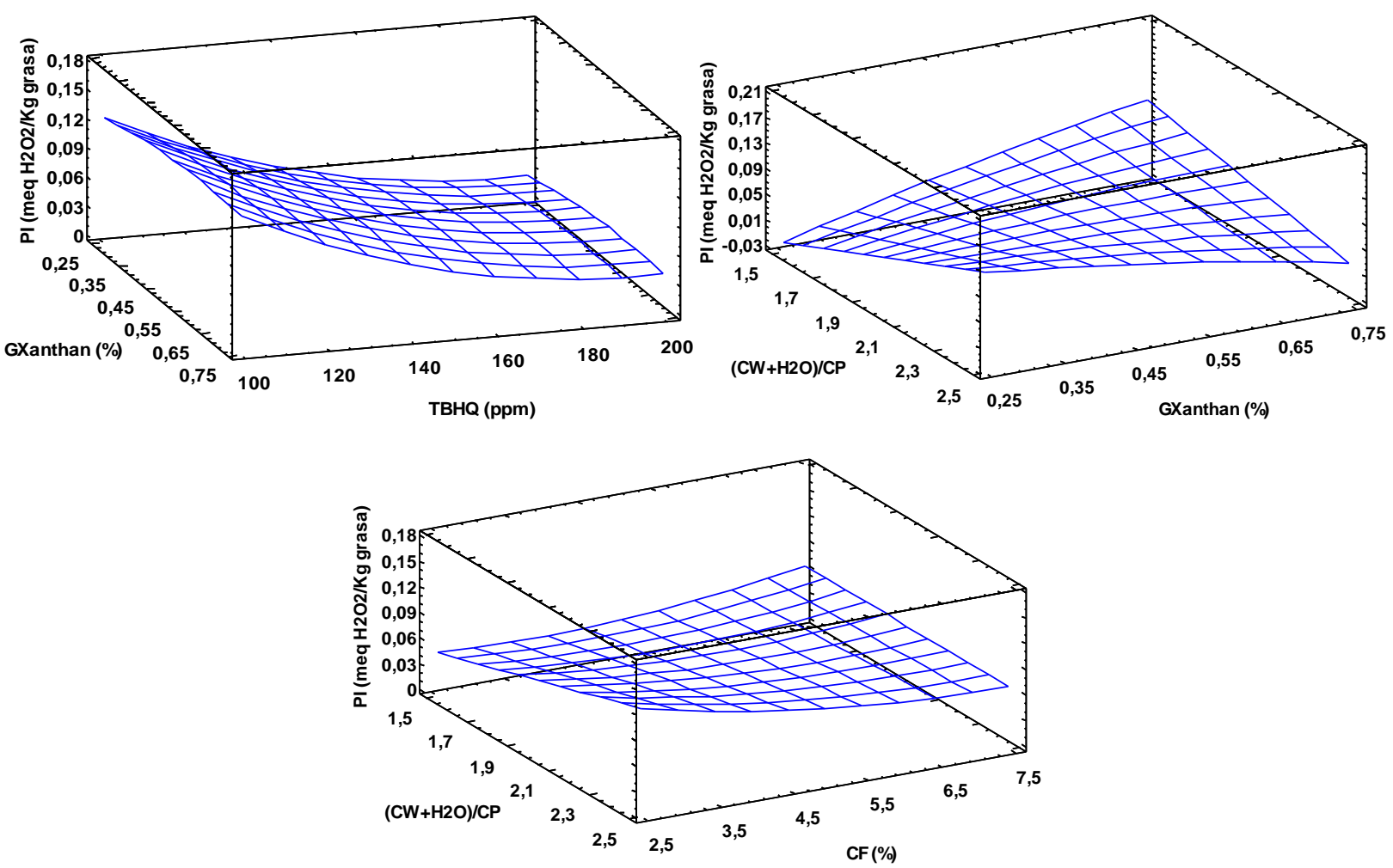

Fig. 5: Plots of PI surface response in function of the independent variables

pulp fiber (Chatsisvili et al., 2012); between -54.0 and $35.0 \mathrm{mV}$ in emulsions with chia oil (Julio et al.,2015); and between -43.6 and $-11.5 \mathrm{mV}$ in emulsions of sunflower oil and sodium caseinate/sodium alginate mixes (Sosa-Herrera et al., 2012). Mirhosseini et al. (2008) reported values between -27.0 and -30.0 for emulsified orange beverages, where the effect of the $\mathrm{G}_{\text {Xanthan }}$ concentration favored the repulsive forces, as in this research.

Emulsion oxidation: Figure 5 presents the PI Surface response plots in function of the independent variables. The ANOVA showed that the PI had statistically significant differences $(\mathrm{p}<0.05)$ with respect to $\mathrm{G}_{\text {Xanthan, }}$ the $\left(\mathrm{CW}+\mathrm{H}_{2} \mathrm{O}\right) / \mathrm{CP}$-fiber percentage interaction, as well as the quadratic effect of TBHQ. However, the changes presented were low, fluctuating between $0.03 \pm 0.03$ and $0.18 \pm 0.02$ meq $\mathrm{H}_{2} \mathrm{O}_{2} / \mathrm{kg}$, indicating minimum oxidation on the fatty acids and surely as consequence of the imposed operation conditions: raw matter in excellent quality conditions (<30 after harvest), short homogenization times, low processing temperatures. It is worth highlighting the effect of TBHQ on PI, acting on its role as antioxidant upon contributing to its diminishing when its concentration increases. Within this context, the hydrophobic antioxidant action in the fat-water interface at high concentrations is more effective by reducing the oxidation of the oily phase (Kishk and Elsheshetawy, 2013).

The negative $\left(\mathrm{CW}+\mathrm{H}_{2} \mathrm{O}\right) / \mathrm{CP}$-fiber percentage interaction increases PI when the emulsion has a high content of aqueous phase and low fiber percentage added, a situation that favors its fluidization during homogenization, occluding greater air and generating smaller particle sizes in the oil drops that increases its surface area and favors oxidation and greater formation of hydro-peroxides. Further, PI presented a tendency to increase with increased $\mathrm{G}_{\text {Xanthan, }}$ in the whole range of the $\left(\mathrm{CW}+\mathrm{H}_{2} \mathrm{O}\right) / \mathrm{CP}$ ratio, being likewise greater when the emulsion is more fluid. This effect could be attributed to the $\mathrm{G}_{\text {Xanthan }}$ capacity to bind to $\mathrm{Fe}^{2+}$ ions in the anionic sites of pyruvate along the polysaccharide chain. Consequently, the level of $\mathrm{Fe}^{2+}$ free ions available to promote lipid oxidation would be reduced, but could be affected by other metals (Qiu et al., 2015). This translates into the fiber's chelating capacity, which has in vitro cationic exchange capacity as mineral binding means; one of the possible consequences is that these ions can be kept from operating in the activation of the lipid oxidative reactions. It has been shown that some fibers have ionic exchange capacity with copper. Additionally, pectin can combine in vitro with bivalent ions, like iron, calcium, copper and zinc (Borderías et al., 2005; Yalegama et al., 2013; Qiu et al., 2015).

Mathematical modeling of the response surfaces: Table 4 and 5 present the estimated regression coefficients of the polynomial surface response models with the corresponding $\mathrm{R}^{2}$ values, lack-of-fit test and the experimental and theoretical or predicted values, besides the Relative Mean Error (RME). 
Adv. J. Food Sci. Technol., 14(3): 77-92, 2018

Table 4: Regression coefficients, $\mathrm{R}^{2}$, and probability values of the lack of fit of the models for the dependent variables

\begin{tabular}{|c|c|c|c|c|c|c|}
\hline Regression coefficients & $a_{w}$ & TS & $\mathrm{L}^{*}$ & $a^{*}$ & $\mathrm{~b}^{*}$ & $\mathrm{R}$ \\
\hline$\overline{\beta_{0}}$ & 0.998 & -5.874 & 90.756 & -7.749 & 9.797 & 1.084 \\
\hline$\beta_{\mathrm{A}}$ & -0.022 & 28.130 & -17.583 & 11.579 & -3.288 & -0.028 \\
\hline$\beta_{\mathrm{B}}$ & -0.100 & -24.517 & 1.256 & 5.054 & -25.411 & -0.069 \\
\hline$\beta_{\mathrm{C}}$ & -0.005 & 2.219 & -1.527 & -0.480 & 1.660 & -0.016 \\
\hline$\beta_{\mathrm{D}} \times 10^{-2}$ & 0.047 & -3.913 & -0.900 & -1.917 & 1.680 & -0.141 \\
\hline$\beta_{A}{ }^{2}$ & 0.004 & -7.618 & 3.229 & -1.912 & 0.167 & -0.022 \\
\hline$\beta_{B}^{2}$ & -0.021 & 7.449 & 3.096 & -7.646 & 6.846 & 0.119 \\
\hline$\beta_{C}^{2} \times 10^{-2}$ & 0.028 & 8.462 & -7.189 & 10.692 & -7.980 & 0.050 \\
\hline$B_{D}{ }^{2} \times 10^{-4}$ & -0.016 & 1.929 & -3.111 & 1.761 & 1.104 & 0.038 \\
\hline$\beta_{A B}$ & 0.012 & 3.417 & -2.988 & -0.622 & 9.204 & 0.035 \\
\hline$\beta_{C W} \times 10^{-2}$ & 0.237 & -54.033 & 55.633 & -30.800 & -2.289 & 0.343 \\
\hline$\beta_{A D} \times 10^{-2}$ & -0.003 & 0.238 & 2.489 & -1.279 & -1.431 & 0.025 \\
\hline$\beta_{B C}$ & 0.002 & 0.737 & -0.627 & 0.672 & -0.479 & 0.004 \\
\hline$\beta_{B D} \times 10^{-3}$ & 0.517 & 50.3 & 37.011 & -2.222 & 9.956 & -0.743 \\
\hline$\beta_{C D} \times 10^{-3}$ & -0.026 & -7.883 & 5.474 & 1.282 & -2.16 & 0.012 \\
\hline $\mathrm{R}^{2}$ & 74.854 & 94.992 & 71.106 & 64.856 & 66.367 & 59.657 \\
\hline Lack of fit (p-value) & 0.600 & 0.8641 & 0.5785 & 0.349 & 0.4751 & 0.207 \\
\hline Regression coefficients & $\mu$ & $\mathrm{D}_{10}$ & $\mathrm{D}_{50}$ & $\mathrm{D}_{90}$ & $\zeta$ & PI \\
\hline$\overline{\beta_{0}}$ & 2785.410 & 91.725 & -109.118 & -562.712 & -70.217 & -0.145 \\
\hline$\beta_{\mathrm{A}}$ & -2042.280 & -55.417 & -139.927 & 844.839 & -14.274 & 0.374 \\
\hline$\beta_{\mathrm{B}}$ & -4894.760 & -81.340 & -3473.790 & -2363.13 & -115.877 & 1.073 \\
\hline$\beta_{\mathrm{C}}$ & 173.046 & 7.565 & 117.114 & -20.842 & 7.235 & 0.001 \\
\hline$\beta_{\mathrm{D}} \times 10^{-2}$ & -351.331 & -43.114 & 1138.260 & 1300.440 & 62.597 & -0.403 \\
\hline$\beta_{A}{ }^{2}$ & 243.066 & 6.585 & -14.060 & -114.147 & 4.668 & 0.0003 \\
\hline$\beta_{B}{ }^{2}$ & -40.003 & 9.266 & 802.784 & 1237.630 & 82.405 & -0.124 \\
\hline$\beta_{C}^{2} \times 10^{-2}$ & 2976.260 & 11.248 & -344.692 & 117.633 & -46.218 & 0.204 \\
\hline$B_{D}^{2} \times 10^{-4}$ & 376.399 & 5.683 & -63.282 & 141.408 & -12.088 & 0.1087 \\
\hline$\beta_{A B}$ & 2102.200 & 29.412 & 1182.400 & 912.778 & 17.611 & -0.415 \\
\hline$\beta_{C W} \times 10^{-2}$ & -2552.670 & -174.21 & 1360.070 & 2545.560 & 27.000 & -1.527 \\
\hline$\beta_{A D} \times 10^{-2}$ & 88.233 & 13.604 & -296.559 & -703.056 & -8.539 & -0.035 \\
\hline$\beta_{B C}$ & 234.707 & -2.754 & -5.183 & -43.800 & -2.869 & -0.019 \\
\hline$\beta_{B D} \times 10^{-3}$ & 7130.000 & 174.322 & 1215.570 & -0.00529 & 1.000 & 0.013 \\
\hline$\beta_{C D} \times 10^{-3}$ & 2351.400 & -19.619 & -488.393 & 20.3333 & -11.344 & 0.103 \\
\hline $\mathrm{R}^{2}$ & 96.400 & 69.367 & 67.625 & 67.0092 & 63.344 & 66.208 \\
\hline Lack of fit (p-value) & 0.875 & 0.570 & 0.4963 & 0.485 & 0.000 & 0.486 \\
\hline
\end{tabular}

Table 5: Experimental and theoretical or predicted values through the mathematical models of the dependent variables of the coconut emulsion

\begin{tabular}{|c|c|c|c|c|}
\hline Variable & Experimental value & $\begin{array}{l}\text { Theoretical or predicted } \\
\text { value }\end{array}$ & Difference & RME \\
\hline$\overline{\mathrm{L}^{*}}$ & $67.5 \pm 0.7$ & 66.4 & -0.906 & 0.404 \\
\hline$a^{*}$ & $3.2 \pm 0.2$ & 3.2 & 0.007 & 1485 \\
\hline$b^{*}$ & $8.6 \pm 0.5$ & 7.9 & 0.771 & 2.451 \\
\hline $\mathrm{R}$ & $0.851 \pm 0.025$ & 0.858 & -0.007 & 0.177 \\
\hline$\mu$ & $741.7 \pm 25.5$ & 776.196 & -34.464 & 0.454 \\
\hline ÍP & $0.142 \pm 0.038$ & 0.141 & 0.001 & 2.304 \\
\hline $\mathrm{D}_{10}$ & $4.3 \pm 0.8$ & 3.4 & 0.958 & 5.748 \\
\hline $\mathrm{D}_{50}$ & $323.7 \pm 43.6$ & 331.5 & -7.791 & 2.962 \\
\hline $\mathrm{D}_{90}$ & $743.0 \pm 65.1$ & 626.9 & 116.164 & 4.084 \\
\hline Potential- $\zeta$ & $-45.6 \pm 2.5$ & -48.2 & 2.653 & 1.878 \\
\hline$a_{w}$ & $0.983 \pm 0.05$ & 0.986 & -0.003 & 0.044 \\
\hline TS & $19.981 \pm 0.303$ & 20.573 & -0.592 & 0.269 \\
\hline
\end{tabular}

RME: Relative mean error

Although the $\mathrm{R}^{2}$ values for the response variables were not sufficiently high, the lack-of-fit test permits determining the exactness of the model to predict the variation, where the high reliability and precision of the response data were confirmed by the RME values by being significantly lower than $10 \%$. In addition, the results did not reveal statistically significant differences $(p>0.05)$ between the responses observed and those predicted, where the regression models agree with the values observed, demonstrating the precision and reliability of the empirical models that resulted significant $(p>0.05)$ in terms of the response variables studied, which indicates that the models were adequate to describe data behavior.

The viscosity and TS variables are critical for optimization, presenting values of 0.964 and 0.95 that indicate that the response surface model explains 95 to $96 \%$ it variation in function of the emulsion's composition and homogenizing process.

Emulsion optimization: Numerical experimental optimization is carried out to obtain optimal values for independent variables, thus, determining the desired response parameters that permit achieving a final product with adequate quality attributes. For this case 
and according to the statistical results found, the criteria were the following: Approximate viscosity of $1000 \mathrm{cP}$ (condition of maximum viscosity permitted by the drier), higher TS percentage, higher $\mathrm{L}^{*}$, lower enzymatic browning and lipid oxidation (< PI and < potential- $\zeta$ ). These response variables were significantly influenced by the $\mathrm{G}_{\text {Xanthan }}$ and fiber percentage, being the variables that seek better emulsion behavior and where the antioxidant becomes a support factor that tends toward the good performance of the $\mathrm{G}_{\text {Xanthan }}$ interaction and percentage of fiber.

The optimal conditions reached by the independent variables were the following: $\left(\mathrm{CW}+\mathrm{H}_{2} \mathrm{O}\right) / \mathrm{CP}=2.0$; $\mathrm{G}_{\text {Xanthan }}=0.5 \%$; Fiber percentage $=5.0$ and $\mathrm{TBHQ}=200$ $\mathrm{mg} / \mathrm{kg}$, with 10-min homogenizing time and controlling emulsification temperature to $30^{\circ} \mathrm{C}$. Table 5 compares the dependent variables of the emulsion obtained from three replicates at the optimal condition and the values predicted by the mathematical model. Note that the values predicted by the models have approximately 95\% acceptance level and can establish the required optimal preparation conditions for coconut emulsions and/or suspensions by adding its own fiber.

\section{CONCLUSION}

The generation of value in the coconut agricultural chain represents a challenge from the research point of view, given that the matrix is quite complex due to its composition and mechanical properties. Development of a coconut based colloid formulation with its original fiber is possible by using statistical tools for its optimization, with the final emulsion obtained a potential and adequate base from the technical point of view, for its use in a future development of a product in coconut powder. The potential use of the fruit and the fiber present could represent a health benefit and a substantial economic boost for its agroindustry.

In general, the intermediate levels of the hydrocolloid and fiber added are those that seek better behavior of the emulsion. The $\left(\mathrm{CW}+\mathrm{H}_{2} \mathrm{O}\right) / \mathrm{CP}$ ratio, although influencing in some specific cases, is not very determining, while the antioxidant becomes a support factor that tends toward the good performance of the hydrocolloid and fiber interaction.

The surface response methodology permitted identifying the principal effects of the dependent variables and their interactions on the attributes of emulsion quality. In general, the components selected and the ranges evaluated of the dependent variables in the formulations were quite correct. A stable emulsion was obtained with important solid content due to the dairy serum action in its surfactant role (assuming a high contribution in reduced free energy in the interphase), the excellent negative electric potential favoring the repulsive forces of the particles and the effect of the hydrocolloid on the rheology of the continuous phase that restricts the mobility of the oily drops and suspended fibers. In addition, the excellent oxidative control was a result of the synergy between the TBHQ action and the controlled preparation temperature.

\section{REFERENCES}

Abascal, D.M. and J. Garcia-Fadrique, 2009. Surface tension and foam stability of commercial calcium and sodium caseinates. FoodHydrocolloid., 23(7): 1848-1852.

Alvarado, J. and J.M. Aguilera, 2001. Métodos para medir propiedades físicas en industrias de alimentos. 1raEdn., Editorial Acribia S.A., Zaragoza.

Anarjan, N., H. Mirhosseini, B.S. Baharin and C.P. Tan, 2010. Effect of processing conditions on physicochemical properties of astaxanthin nanodispersions. Food Chem., 123(2): 477-483.

AOAC (Association of Official Analytical Chemists), 1990. Official Methods of Analysis. In: Horwitz,W. (Ed.), 15ª Edn., Washington.

Appaiah, P., L. Sunil, P.K. Prasanth Kumar and A.G. Gopala Krishna, 2015. Physico-chemical characteristics and stability aspects of coconut water and kernel at different stages of maturity. J. Food Sci. Tech., 52(8): 5196-5203.

Assa, R.R., J.L. Konan-Konan, A. Prades, J.Nemlin and E. Koffi, 2010.Physicochemical characteristics of kernel during fruit maturation of four coconut cultivars (Cocos nucifera L.). Afr. J.Biotechnol., 9(14): 2136-2144.

Bae, E.K. and S.J. Lee, 2008. Microencapsulation of avocado oil by spray drying using whey protein and maltodextrin. J. Microencapsul., 25(8): 549560.

Borda, M.D.L.A., 2011. Formulación de una base para aderezo de ensaladas con características de alimento funcional. Tesis de Maestría, Universidad Tecnológica Nacional. Buenos Aires, pp: 259.

Borderías, A.J., I. Sánchez-Alonso and M. PérezMateos, 2005. New applications of fibres in foods: Addition to fishery products. Trends Food Sci. Tech., 16(10): 458-465.

Castro, A., G. Céspedes, S. Carballo, B. Bergenståhl and E. Tornberg, 2013. Dietary fiber, fructooligosaccharides, and physicochemical properties of homogenized aqueous suspensions of yacon (Smallanthussonchifolius). Food Res. Int., 50(1): 392-400.

Chatsisvili, N.T., I. Amvrosiadis and V. Kiosseoglou, 2012. Physicochemical properties of a dressingtype $\mathrm{o} / \mathrm{w}$ emulsion as influenced by orange pulp fiber incorporation. LWT-Food Sci.Technol., 46(1): 335-340.

Chiewchan, N., C. Phungamngoen and S. Siriwattanayothin, 2006. Effect of homogenizing pressure and sterilizing condition on quality of canned high fat coconut milk. J. Food Eng., 73(1): 38-44. 
Cortés, R.M. and B.A. Chiralt, 2008. Cinética de los cambios de color en manzana deshidratada por aire fortificada con vitamina E. Vitae, 15(1): 8-16.

Damar, S., 2006. Processing of coconut water with high pressure carbon dioxide technology. Ph.D. Thesis, University of Florida, Florida.

Day, L., M. Xu, S.K. Øiseth, Y. Hemar and L. Lundin, 2010. Control of morphological and rheological properties of carrot cell wall particle dispersions through processing. Food Bioprocess Tech., 3(6): 928-934.

DebMandal, M. and S. Mandal, 2011. Coconut (Cocos nucifera L.: Arecaceae): In health promotion and disease prevention. Asian Pacific J. Trop. Med., 4(3): 241-247.

Dickinson, E. and G. Stainsby, 1982. Colloids in Food. Applied Science Publishers.

Elleuch, M., D. Bedigian, O. Roiseux, S. Besbes, C. Blecker and H. Attia, 2011. Dietary fibre and fibrerich by-products of food processing: Characterisation, technological functionality and commercial applications: A review. Food Chem., 124(2): 411-421.

Estevinho, B.N., A.M. Damas, P. Martins and F. Rocha, 2014. Microencapsulation of $\beta$-galactosidase with different biopolymers by a spray-drying process. Food Res. Int., 64: 134-140.

Ge, L., J.W. Yong, S.N. Tan, X.H. Yang and E.S. Ong, 2006. Analysis of cytokinin nucleotides in coconut (Cocos nuciferaL.) water using capillary zone electrophoresis-tandem mass spectrometry after solid-phase extraction. J. Chromatoqr. A, 1133(12): $322-331$.

Gilabert, E.J., 1998. Medida del color. Universidad Politécnica de Valencia, Servicio de publicaciones, Valencia.

González-Tello, P., F. Camacho, E.M. Guadix, G. Luzón and P.A. González, 2007. Density, viscosity and surface tension of whey protein concentrate solutions. J. Food Process Eng., 32(2): 235-247.

Guarte, R.C., W. Mühlbauer and M. Kellert, 1996. Drying characteristics of copra and quality of copra and coconut oil. Postharvest Biol. Tec., 9(3): 361372.

Haseena, M., K.V. Kasturi Bai and S. Padmanabhan, 2010. Post-harvest quality and shelf-life of tender coconut. J. Food Sci. Tech., 47(6): 686-689.

Homayoonfal, M., F. Khodaiyan and M. Mousavi, 2015. Modelling and optimising of physicochemical features of walnut-oil beverage emulsions by implementation of response surface methodology: Effect of preparation conditions on emulsion stability. Food Chem.,174: 649-659.

Hornero-Méndez, D., A. Pérez-Gálvez and M.I. Mínguez-Mosquera, 2001. A rapid spectrophotometric method for the determination of peroxide value in food lipids with high carotenoid content. J.Am. Oil Chem. Soc., 78(11): 1151-1155.
Jayalekshmy, A., C. Arummaghan, S. Narayanan and A.G. Mathew, 1986. Changes in the chemical composition of coconut water during maturation. J. Food Sci. Tech., 23: 203-207.

Jayme, M.L., D.E. Dunstan and M.L. Gee, 1999.Zeta potentials of gum arabicstabilised oil in water emulsions. Food Hydrocolloid., 13(6): 459-465.

Jirapeangtong, K., S. Siriwatanayothin and N. Chiewchan, 2008. Effects of coconut sugar and stabilizing agents on stability and apparent viscosity of high-fat coconut milk. J. Food Eng., 87(3): 422-427.

Julio, L.M., V.Y. Ixtaina, M.A. Fernández, R.M.T. Sánchez, J.R. Wagner et al., 2015. Chia seed oilin-water emulsions as potential delivery systems of $\omega-3$ fatty acids. J. Food Eng., 162: 48-55.

Khuenpet, K., N. Charoenjarasrerk, S. Jaijit, S. Arayapoonpong and W. Jittanit, 2016. Investigation of suitable spray drying conditions for sugarcane juice powder production with an energy consumption study. Agr. Nat. Resour., 50(2): 139-145.

Kishk, Y.F.M. and H.E. Elsheshetawy, 2013. Effect of ginger powder on the mayonnaise oxidative stability, rheological measurements, and sensory characteristics. Ann. Agr. Sci., 58(2): 213-220.

Klinkesorn, U., P. Sophanodora, P. Chinachoti and D.J. McClements, 2004. Stability and rheology of corn oil-in-water emulsions containing maltodextrin. Food Res. Int., 37(9): 851-859.

Kuhn, K.R. and R.L. Cunha, 2012. Flaxseed oil- Whey protein isolate emulsions: Effect of high pressure homogenization. J. Food Eng., 111(2): 449-457.

Laux, D., O. Gibert, J.Y. Ferrandis, M. Valente and A. Prades, 2014. Ultrasonic evaluation of coconut water shear viscosity. J. Food Eng., 126: 62-64.

Li, J.M. and S.P. Nie, 2016. The functional and nutritional aspects of hydrocolloids in foods. Food Hydrocolloid, 53: 46-61.

López-Sánchez, P., J. Nijsse, H.C. Blonk, L. Bialek, S. Schumm and M. Langton, 2011. Effect of mechanical and thermal treatments on the microstructure and rheological properties of carrot, broccoli and tomato dispersions. J. Sci. Food Agr., 91(2): 207-217.

Luengwilai, K., D.M. Beckles, O. Pluemjit and J. Siriphanich, 2014. Postharvest quality and storage life of 'Makapuno' coconut (Cocos nucifera L.). Sci.Hortic-Amsterdam, 175: 105-110.

Makri, E.A. and G.I.Doxastakis, 2007. Surface tension of Phaseolus vulgaris and coccineus proteins and effect of polysaccharides on their foaming properties. Food Chem., 101(1): 37-48.

Malvern Instruments, 2004. Zetasizer Nano Series User Manual. Department of Biochemistry Biophysics Facility, University of Chambridge. 
Mantzouridou, F., A. Spanou and V. Kiosseoglou, 2012. An inulin-based dressing emulsion as a potential probiotic food carrier. Food Res. Int., 46(1): 260-269.

Marina, A.M., Y.B. Che Man and I. Amin, 2009. Virgin coconut oil: Emerging functional food oil. Trends Food Sci. Tech., 20(10): 481-487.

McClements, D.J., 2004a. Food Emulsions: Principles, Practices, and Techniques. 2nd Edn., CRC Press, Boca Raton, Fla, pp: 609.

McClements, D.J., 2004b. Protein-stabilized emulsions. Curr. Opin. Colloid In., 9(5): 305-313.

Millqvist-Fureby, A. and P. Smith, 2007. In-situ lecithination of dairy powders in spray-drying for confectionery applications. Food Hydrocolloid.,21(5-6): 920-927.

Mirhosseini, H., C. Ping Tan, N.S.A. Hamid and S. Yusof, 2008. Effect of Arabic gum, xanthan gum and orange oil contents on $\zeta$-potential, conductivity, stability, size index and $\mathrm{pH}$ of orange beverage emulsion. Colloid. Surface A, 315(1-3): 47-56.

Niu, F., Y. Zhang, C. Chang, W. Pan, W. Sun, Y. Suand Y. Yang, 2017. Influence of the preparation method on the structure formed by ovalbumin/gum arabic to observe the stability of oil-in-water emulsion. Food Hydrocolloid., 63: 602-610.

Ng, S.P., O.M. Lai, F. Abas, H.K. Lim and C.P. Tan, 2014. Stability of a concentrated oil-in-water emulsion model prepared using palm olein-based diacylglycerol/virgin coconut oil blends: Effects of the rheological properties, droplet size distribution and microstructure. Food Res. Int. 64: 919-930.

Ochoa-Velasco, C.E., M. Cruz-González and J.Á. Guerrero-Beltrán, 2014. Ultraviolet-C light inactivation of Escherichia coli and Salmonella typhimurium in coconut (Cocos nucifera L.) milk. Innovat. Food Sci. Emerg. Technol., 26: 199-204.

Phisut, N., 2012. Spray drying technique of fruit juice powder: Some factors influencing the properties of product. Int. Food Res. J., 19(4): 1297-1306.

Phungamngoen, C., N. Chiewchan and S. Siriwatanayothin, 2004. Effect of some stabilizers on the quality of canned high fat coconut milk. J. KMUTT's. Res. Develop., 27: 376-390.

Piorkowski, D.T. and D.J. McClements, 2014. Beverage emulsions: Recent developments in formulation, production, and applications. Food Hydrocolloid., 42: 5-41.

Peamprasart, T. and N. Chiewchan, 2006. Effect of fat content and preheat treatment on the apparent viscosity of coconut milk after homogenization. J. Food Eng., 77(3): 653-658.

Pelegrine, D.H., F.C. Silva and C.A. Gasparetto, 2002. Rheological behavior of pineapple and mango pulps. LWT-Food Sci. Technol., 35(8): 645-648.
Prado, F.C., J.D.D. Lindner, J. Inaba, V. ThomazSoccol, S.K. Brar and C.R. Soccol, 2015. Development and evaluation of a fermented coconut water beverage with potential health benefits. J. Funct. Foods, 12: 489-497.

Prieto, W.H., A.M. Iguti and M. Nitz, 2011. Drying evaluation of green coconut pulp for obtaining a snack-like product. Proc. Food Sci., 1: 1618-1627.

Purkayastha, M.D., D. Kalita, N.K. Mahnot, C.L. Mahanta, M. Mandal and M.K. Chaudhuri, 2012. Effect of L-ascorbic acid addition on the quality attributes of micro-filtered coconut water stored at $4^{\circ} \mathrm{C}$. Innov. Food Sci. Emerg., 16: 69-79.

Qiu, C., M. Zhao, E.A. Decker and D.J. McClements, 2015. Influence of anionic dietary fibers (xanthan gum and pectin) on oxidative stability and lipid digestibility of wheat protein-stabilized fish oil-inwater emulsion. Food Res. Int., 74: 131-139.

Raghavendra, S.N., S.R. Ramachandra-Swamy, N.K. Rastogi, K.S.M.S. Raghavarao, S. Kumar and R.N. Tharanathan, 2006. Grinding characteristics and hydration properties of coconut residue: A source of dietary fiber. J. Food Eng., 72(3): 281-286.

Raghavendra, S.N. and K.S.M.S. Raghavarao, 2010. Effect of different treatments for the destabilization of coconut milk emulsion. J. Food Eng., 97(3): 341-347.

Rezvani, E., G. Schleining and A.R. Taherian, 2012. Assessment of physical and mechanical properties of orange oil-in-water beverage emulsions using response surface methodology. LWT-Food Sci. Technol., 48(1): 82-88.

Salager, J.L., 2005. Tensión interfacial. Cuaderno FIRP S203-A. A. Módulo de enseñanza en fenómenos interfaciales. Universidad de los Andes, MeridaVenezuela, pp: 4-5.

Santoso, U., K. Kubo, T. Ota, T. Tadokoro and A. Maekawa, 1996. Nutrient composition of kopyor coconuts (Cocos nucifera L.). Food Chem., 57(2): 299-304.

Simuang, J., N. Chiewchan and A. Tansakul, 2004. Effects of fat content and temperatura on the apparentv is cosity of coconut milk. J. Food Eng., 64(2): 193-197.

Siriphanich, J., P. Saradhuldhat, T. Romphophak, K. Krisanapook, S. Pathaveerat and S. Tongchitpakdee, 2011. Coconut (Cocos nucifera L.). In: Yahia, E. (Ed.), Postharvest-Biology and Technology of Tropical and Subtropical Fruits, Cocona to Mango. Woodhead Publishing in Food Science Technology and Nutrition, Cambridge, UK, 3: 8-33.

Solangi, A.H.and M.Z. Iqbal, 2011. Chemical composition of meat (kernel) and nut water of major coconut (cocos nucifera L.) Cultivars at coastalareaofPakistan. Pak. J. Bot, 43(1): 357-363. 
Sosa-Herrera, M.G., I.E. Lozano-Esquivel, Y.R. Ponce de León-Ramírez and L.P. Martínez-Padilla, 2012. Effect of added calcium chloride on the physicochemical and rheological properties of aqueous mixtures of sodium caseinate/sodium alginate and respective oil-in-water emulsions. Food Hydrocolloid., 29(1): 175-184.

Souza, C.J.F. and E.E. Garcia-Rojas, 2017. Interpolymeric complexing between egg white proteins and xanthan gum: Effect of salt and protein/polysaccharide ratio. Food Hydrocolloid., 66: 268-275.

Tan, T.C., L.H. Cheng, R. Bhat, G. Rusul and A.M. Easa, 2014. Composition, physicochemical properties and thermal inactivation kinetics of polyphenol oxidase and peroxidase from coconut (Cocos nucifera) water obtained from immature, mature and overly-mature coconut. Food Chem., 142: $121-128$.

Tangsuphoom, N. and J.N. Coupland, 2005. Effect of heating and homogenization on the stability of coconut milk emulsions. J. Food Sci., 70(8): e466e700.

Tangsuphoom, N. and J.N. Coupland, 2008. Effect of $\mathrm{pH}$ and ionic strength on the physicochemical properties of coconut milk emulsions. J. Food Sci., 73(6): E274-E280.

Tangsuphoom, N. and J.N. Coupland, 2009.Effect of surface-active stabilizers on the surface properties of coconut milk emulsions. Food Hydrocolloid., 23: 1801-1809.

Thaiphanit, S., G. Schleining and P. Anprung, 2016.Effects of coconut (Cocos nucifera L.) protein hydrolysates obtained from enzymatic hydrolysis on the stability and rheological properties of oil-in-water emulsions. Food Hydrocolloid., 60: 252-264.
Tipvarakarnkoon, T., U. Einhorn-Stoll and B. Senge, 2010. Effect of modified Acacia gum (SUPER $\mathrm{GUM}^{\mathrm{TM}}$ ) on the stabilization of coconut $\mathrm{o} / \mathrm{w}$ emulsions. Food Hydrocolloid, 24: 595-601.

Tontul, I. and A. Topuz, 2017. Spray-drying of fruit and vegetable juices: Effect of drying conditions on the product yield and physical properties. Trends Food Sci. Tech, 63: 91-102.

Trinidad, T.P., A.C. Mallillin, D.H. Valdez, A.S. Loyola, F.C. Askali-Mercado et al., 2006. Dietary fiber from coconut flour: A functional food. Innov. Food Sci. Emerg., 7(4): 309-317.

Valencia, C., M.C. Sánchez, A. Ciruelos and C. Gallegos, 2004. Influence of tomato paste processing on the linear viscoelasticity of tomato ketchup. Food Sci. Technol. Int., 10(2): 95-100.

Vitali, A.A., M.P. Soler and M.P. Rao, 1985. Rheological Behavior of Coconut Milk. In: Maguer, M.L. and P. Jelen (Eds.), Food Engineering and Process Applications. Transport Phenomena: Elsevier Applied Science, London, 1: 33-38.

Waisundara, V.Y., C.O. Perera and P.J. Barlow, 2007. Effect of different pre-treatments of fresh coconut kernels on some of the quality attributes of the coconut milk extracted. Food Chem., 101(02): 771777.

Wallecan, J., C. McCrae, S.J.J. Debon, J. Dong and J. Mazoyer, 2015. Emulsifying and stabilizing properties of functionalized orange pulp fibers. Food Hydrocolloid., 47: 115-123.

Yalegama, L.L.W.C., D.N. Karunaratne, R. Sivakanesan and C. Jayasekara, 2013. Chemical and functional properties of fibre concentrates obtained from by-products of coconut kernel. FoodChem., 141(1): 124-130. 